\title{
Anayasa Mahkemesi Kararları Işı̆ğında Yüikseköğretim Öğrencileri Disiplin Rejiminin Suçta ve Cezada Kanunilik İlkesi Bakımından Değerlendirilmesi
}

\author{
Evaluation of the University Disciplinary Regime in the Light of the \\ Constitutional Court Decisions in terms of the Principle of Legality
}

\author{
İlhami Öztürk ${ }^{*}$ (iD, Arif Emre Sümer ${ }^{* *}$ (iD)
}

\section{öz}

Disiplin suçları, belirli bir meslek grubu ile statü sahibi kişilerin oluşturduğu kısmi düzenin korunması için bu kimselere yönelik öngörülen yasak ve yükümlülükler anlamına gelirken; disiplin cezaları, bu yasak ve yükümlülüklere uyulmaması halinde tatbik edilecek idari yaptırımları ifade eder. Hukukumuzda çeşitli meslek mensubu ya da statü sahibi kişilere yönelik disiplin suç ve cezaları öngören düzenlemeler mevcuttur. Bunlardan biri de yükseköğretim kurumlarında eğitim-öğretim gören öğrencilerin disiplin rejimini düzenleyen, 2547 sayılı Yükseköğretim Kanunu ile bu Kanuna dayanılarak çıkarılan Yükseköğretim Kurumları Öğrenci Disiplin Yönetmeliğidir. Doktrinde ve yargı içtihatlarında suçta ve cezada kanunilik ilkesi de dahil olmak üzere, ceza hukukunun temel ilkelerinin disiplin suç ve cezaları bakımından da geçerli olduğu ifade edilmektedir. Çalışmamızda, yükseköğretim öğrencileri disiplin rejiminin suçta ve cezada kanunilik ilkesine uygunluğu Anayasa Mahkemesi kararları ışığında ele alınacaktır.

Anahtar Kelimeler: Disiplin suçu, Disiplin cezası, Kanunilik ilkesi, Yükseköğretim öğrencileri, Yükseköğretim kurumları

\section{ABSTRACT}

While disciplinary offenses mean prohibitions and obligations foreseen for a certain professional group and status holders in order to protect the order created by these persons; Disciplinary penalties refer to the administrative sanctions stipulated in case of failure to comply with these prohibitions and obligations. In our law, there are regulations stipulating disciplinary crimes and penalties for persons with various professions and status. One of them is the Higher Education Law No. 2547, which regulates the disciplinary regime of students studying in higher education institutions, and the Higher Education Institutions Student Discipline Regulation issued based on this Law. It is stated in the doctrine and jurisprudence that the basic principles of criminal law, including the principle of legality in crime and punishment, are valid in terms of disciplinary crimes and penalties. In our study, in the light of the decisions of the Constitutional Court, the compliance of the disciplinary regime of higher education students with the principle of legality in crime and punishment will be discussed.

Keywords: Disciplinary offense, Disciplinary punishment, Principle of legality, Higher education students, Higher education institutions

* Doç. Dr., İzmir Bakırçay Üniversitesi Hukuk Fakültesi, Mali Hukuk Anabilim Dalı, ORCID: 0000-0001-9828-8861.

** Arş. Gör., İzmir Bakırçay Üniversitesi Hukuk Fakültesi, Ceza ve Ceza Muhakemesi Hukuku Anabilim Dalı, arifemre. sumer@bakircay.edu.tr, ORCID: 0000-0001-7382-4922.

Sorumlu Yazar/Correspondence Author: İlhami Öztürk

E-posta/E-mail: ilhami.ozturk@bakircay.edu.tr 


\section{Giriş}

Kamu hizmetlerinin daha iyi yürütülebilmesi için bu hizmetlerle ilişkili kişilerin uyması gereken birtakım kurallar ile yükümlülükler öngörülmüştür. Bu kural, yasak ve yükümlülüklere uyulmaması halinde ilgili kişilere tatbik edilen idari yaptırımlara disiplin cezaları denir. Hukukumuzda kamu hizmetleriyle ilişkili tüm kişiler için geçerli olacak ortak bir disiplin rejimi bulunmayıp, her bir meslek ya da statü mensubu kişiler için ayrı ayrı disiplin kuralları öngörülmüştür. Örneğin, genel nitelikte bir düzenleme olan ve özel kanunlarda hüküm bulunmaması hallerinde tüm devlet memurları hakkında uygulanacak disiplin suç ve cezalarına 657 sayılı Devlet Memurları Kanunu'nda ${ }^{1}$ (DMK) yer verilmiştir. Avukatlık mesleği mensupları için öngörülen disiplin suç ve cezalarına 1136 sayılı Avukatlık Kanunu’nda ${ }^{2}$, yükseköğretim kurumlarında öğrenci olan kişiler için öngörülen disiplin hükümlerine ise 2547 sayılı Yükseköğretim Kanunu³ ile bu Kanuna dayanarak çıarılan Yükseköğretim Kurumları Öğrenci Disiplin Yönetmeliği’nde ${ }^{4}$ yer verilmiştir.

İdare hukuku ile ceza hukukunun kesişim alanında kalan disiplin hukukuna, ceza hukukunun temel ilkelerinin uygulanacağı bugün yerleşmiş bir görüştür. Ancak ceza hukukunun bazı müesseseleri disiplin hukukunda ceza hukukunda olduğu kadar katı bir şekilde uygulanmaz. Nitekim Anayasa Mahkemesi ile Danıştay da bu doğrultuda hüküm tesis etmektedir. Ezcümle, disiplin suç ve cezaları bakımından geçerli olan ilkelerden biri de suçta ve cezada kanunilik ilkesidir. Bu çalışmada, Anayasa Mahkemesi kararları ışığında yükseköğretim kurumlarında eğitim-öğretim gören öğrenciler için öngörülen disiplin suç ve cezalarının, suçta ve cezada kanunilik ilkesine uygunluğu tetkik edilecektir.

\section{DisiPLIN SUÇ VE CEZASI KAVRAMLARI ILE YÜKSEKÖĞRETIM ÖĞRENCILERi IÇiN ÖNGÖRÜLEN DISIPLIN REJIMI}

\section{A. DISIPLIN SUÇ VE CEZALARI}

Disiplin kavramı sözlükte; "Bir topluluğun, yasalarına ve düzenle ilgili yazılı veya yazısız kurallarına titizlik ve özenle uyması durumu, sıkı düzen, düzence, düzen bağı, zapturapt” "olarak ifade edilmektedir. ${ }^{5}$ Disiplin kavramının hukuk dilindeki anlamı da sözlükteki tanımıyla paraleldir6 .

Disiplin suçları, belirli bir meslek veya statü mensubu kişiler için öngörülen yasaklara uyulmaması ve yükümlülüklerin yerine getirilmemesi şeklindeki fiilleri ifade eder ${ }^{7}$. Disiplin cezaları ise belirli

1 Devlet Memurları Kanunu, Kanun Numarası: 657, Kabul Tarihi: 14.7.1965, RG. 23.7.1965/12056.

2 Avukatlık Kanunu, Kanun Numarası: 1136, Kabul Tarihi: 19.3.1969, RG. 7.4.1969/13168.

3 Yükseköğretim Kanunu, Kanun Numarası: 2547, Kabul Tarihi: 4.11.1981, RG. 6.11.1981/17506.

4 Yükseköğretim Kurumları Öğrenci Disiplin Yönetmeliği, RG. 18.08.2012/28388.

5 Türk Dil Kurumu Sözlüğü, <https://sozluk.gov.tr/> Erişim Tarihi 30 Mart 2021.

6 Bu kavram hukuk sözlüğünde; "Bir topluluğu yönetmeye yarayan yasa ve kuralların tamamı; düzen; bir toplulukta kurallara tam olarak gösterilen uyum” şeklinde tanımlanmaktadır. Tanım için bkz. Ejder Yılmaz, Hukuk Sözlüğü (10. Baskı, Yetkin Yayınları 2011) 329; Disiplin yalnızca kamu kurum ve kuruluşlarının değil, toplumun her kesiminin ve sosyal organizasyonlarının olmazsa olmaz bir unsurudur. Bkz. Celal Işıklar, Teoride ve Uygulamada Kamu Disiplin Yaptırımları (1 .Baskı, Adalet Yayınevi 2019) 47.

7 Ramazan Çağlayan, İdare Hukuku Dersleri (7. Baskı, Seçkin Yayıncılık 2019) 524; Bahtiyar Akyılmaz, 'Anayasal Esaslar 
bir meslek grubu ya da statüye mensubiyet kapsamında, bu meslek ya da statü içi düzenin tesis edilebilmesi ve ilgili kişilerin kendileri için öngörülen yükümlülüklere uymalarının sağlanması için uygulanan idari cezalar şeklinde tanımlanabilir ${ }^{8}$. Disiplin cezaları; idarenin bir yargı kararı olmadan, kendisine kanunla verilen yetkiye dayanarak idari düzenin sağlanması için uyguladığı “idari yaptırımlar"dan biridir?.

Disiplin yaptırımları, bir kamu veya özel teşkilat düzenini devam ettirmek, onun verimli, süratli ve yararlı bir biçimde çalışmasını sağlamak, onur ve saygınlığını korumak amacıyla tesis edilirler. Özellikle kamu görevi yürüten bireyler açısından disiplin cezalarının amacı, kamu görevlisini görevine bağlamak, kamu hizmetinin gereği gibi yürütülmesini temin etmektir. Disiplin cezaları kamu hizmetlerinin gereği gibi yapılması ve memurların kanunla belirlenen düzen içerisinde uyumlu hareket etmeleri amacıyla uygulanır. Disiplin hukuku kapsamında, kamu görevlilerinin işlem ve eylem tarzlarıyla ilgili bazı sınırlamalar getirilmesi, belirtilen bu meşru temellere dayanır. Disiplin cezaları, kamu hizmetinin gereği gibi ve belli bir düzen içerisinde yürütülmesi bakımından kamu görevlilerinin mevzuat uyarınca yerine getirmek zorunda oldukları ödev ve sorumlulukları ifa etmemeleri veya mevzuatta yasaklanan fiilleri işlemeleri durumunda uygulanan yaptırımlardır. Disiplin cezalarının, memurlar ve diğer kamu görevlilerinin özlük hakları üzerinde doğrudan ve önemli sonuçlar doğurmaları sebebiyle bireysel ve sübjektif etkileri bulunduğu gibi kamu görevinin gereği gibi sürdürülmesi ve kamu düzeninin sağlanması bakımından objektif ve kamusal önem taşıyan yönleri de mevcuttur. Disiplin cezaları ile kamu hizmetinin zamanında ve gereği gibi yerine getirilmesi bir başka ifadeyle kamu yararı ve kamu düzeninin tesisi ve temini amaçlanmaktadır. Niteliği gereği öteki idari işlemlerden farklılık arz eden disiplin cezası işlemi, sıkı şekil şartına bağlı olarak uygulanabilmekte, disiplin soruşturmalarının yapılmasında izlenecek yöntem, ceza verilecek fiiller ve ceza vermeye yetkili makam ve kurullar, bu organların oluşumu, çalışma usulü, karar oluşturması, bu kararlara itiraz ve bütün bu sürecin her aşaması için öngörülen süre koşulları pozitif olarak mevzuatta belirlenmektedir ${ }^{10}$.

Çerçevesinde Kamu Personeli Disiplin Hukuku ve Uygulamadaki Sorunlar' (2002) 6(2) Ankara Hacı Bayram Veli Üniversitesi Hukuk Fakültesi Dergisi 241, 242; Bahattin Duman, Yükseköğretim Ceza ve Disiplin Soruşturması (5. Baskı, Seçkin Yayıncılık 2014) 17.

8 Ali D. Ulusoy, İdari Yapttrımlar (1. Baskı, On İki Levha Yayıncılık 2013) 149; Disiplin cezası kavramı hukuk sözlüğünde; "Mevzuatın öngördüğ̈̈ düzen kurallarına uymama halinde uygulanacak olan idari cezalar; kamu görevlerinin gereği gibi görülebilmesi için görevliler hakkında uygulanan cezalar" şeklinde tanımlanmaktadır. Bkz. Yılmaz (n 6) 330; Disiplin cezası kavramı Anayasa Mahkemesinin bir kararında şu şekilde tanımlanmıştır: "Disiplin cezaları, kamu hizmetlerinin yürütülmesi ve kamu yararının devamlliğının sağlanması amacıyla yasal olarak düzenlenmiş idari yaptırımlardır. Kamu hizmetlerini yürütenlerin görev anlayışları, yetki ve sorumlulukları kamu hizmeti ve hizmet gerekleri ile sinırlandırılmış; bu sınırlar dışına çıkanların ise disiplin cezaları ile cezalandırılmaları ilgili kanunlarda öngörü̈lmüştür.", Anayasa Mahkemesi, E. 2018/30, K. 2018/94, T. 25.09.2018.

9 Haluk Toroslu, Ceza Müeyyidesi (1. Baskı, Savaş Yayınevi 2010) 14.

10 Uğur Yiğit ve İlhami Öztürk, Yargı Hukuku (1. Baskı, Adalet Yayınevi 2020) 98; Anılan eserde; disiplin hukukunun niteliği ve doğasına uygun olarak Anayasa Mahkemesi üyeleri, Yargıtay üyeleri, Danıştay üyeleri ve Sayıştay üyelerinde olduğu gibi Hâkimler ve Savcılar Kurulu üyeleri de disiplin hükümlerine tabi kılınmış iken Türk Hukukunda disiplin hükümlerine tabi tutulmayan kamu personelinin bulunduğu, örneğin, 2499 (Mülga) Sermaye Piyasası Kanunu ile yürürlükte olan 6362 sayılı Sermaye Piyasası Kanunu’nda Sermaye Piyasası Kurulu (SPK) üyelerine disiplin cezası verilmesine ilişkin hükme yer verilmemiş olduğu, böylece 2499 sayılı Kanun’un yayım tarihi olan 30.07.1981 tarihinden bugüne Sermaye Piyasası Kurulu üyeleri disiplin hükümlerine tabi kılınmadığı, anılan kanunlarda yer alan idari ve mali özerkliğe sahip olma, Kanunla ve mevzuatla kendisine verilen görev ve yetkileri kendi sorumluluğu altında bağımsız 
Bahsedilen bu meslek veya statü sahibi kişilerin oluşturduğu düzen kamu hizmetlerini ilgilendirdiği için, bu hizmetlerin sürekli ve düzenli bir şekilde sürdürebilmesi maksadıyla ceza hukukundan farklı birtakım kurallara ihtiyaç vardır ${ }^{11}$. Bu sebeplerle Devlet, kamu hizmetlerinin aksamaması için bu hizmetlerle ilişkili kimseler için disiplin suç ve cezaları belirler ${ }^{12}$.

Her meslek veya statü mensubu kişi bakımından geçerli olacak bir genel disiplin rejimi bulunmamaktadır ${ }^{13}$. Farklı meslek grubu ya da statüler itibarıyla farklı disiplin suçları ve bu suçlar karşılı̆̆ında öngörülen disiplin cezaları sevk edilmiştir. Ceza ve idare hukukunu ilgilendiren disiplin cezaları; kamu görevlilerine verilen disiplin cezaları, öğrencilere verilen disiplin cezaları ve meslek mensuplarına yönelik disiplin cezaları olmak üzere üç ana başlıkta toplanabilir ${ }^{14}$. Örneğin devlet memurlarının işleyebileceği disiplin suçları ve bunlar karşılığında öngörülen yaptırımlar 657 sayılı Devlet Memurları Kanunu'nda (DMK), askeri personellerin disiplin rejimi 6143 sayılı Türk Silahlı Kuvvetleri Disiplin Kanunu’nda ${ }^{15}$, Emniyet Genel Müdürlüğü, Jandarma Genel Komutanlığı ve Sahil Güvenlik Komutanlığı personeline ilişkin disiplinsizlik ve cezaları 7068 sayılı Genel Kolluk Disiplin Hükümleri Hakkında Kanun Hükmünde Kararnamenin Kabul Edilmesine Dair Kanun'da ${ }^{16}$, avukatlık mesleği mensuplarının disiplin rejimi 1136 sayılı Avukatlık Kanunu’nda ve yükseköğretim kurumları öğrencilerinin disiplin rejimi 2547 sayılı Yükseköğretim Kanunu ile Yükseköğretim Kurumları Öğrenci Disiplin Yönetmeliğinde düzenlenmiştir.

Buna ek olarak, disiplin hükümleri, ilk derece ve istinaf mahkemeleri hâkim ve savcıları için Anayasa'nın 140/3, 144 (savcılar yönünden) ve 159'uncu maddeleri ile 2802 sayılı Hâkimler ve Savcılar Kanunu $^{17}$, 5235 sayılı Adlî Yargı İlk Derece Mahkemeleri ile Bölge Adliye Mahkemelerinin Kuruluş, Görev ve Yetkileri Hakkında Kanun ${ }^{18}$ ile 6087 sayılı Hâkimler ve Savcılar Kurulu Kanunu'nda ${ }^{19}$, Yargıtay, Danıştay üyeleri için Anayasa’nın 140/3 maddesi ile Yargıtay ve Danıştay Kanunlarında ${ }^{20}$,

olarak yerine getirme ve kullanma, hiçbir organ, makam, merci veya kişinin Kurulun kararlarını etkilemek amacıyla emir ve talimat veremeyeceği yönündeki hükümlerin tek başına Sermaye Piyasası Kurulu üyelerinin disiplin hükümlerinden bağışık tutulmasına haklı ve yeterli bir dayanak teşkil etmeyeceği görüşüne yer verilmiştir.

11 Zehreddin Aslan ve Halil Altındağ, Memurların Disiplin ve Ceza Soruşturması (2. Baskı, Seçkin Yayıncılık 2019) 27; Veysel Candan Canoğlu, 'Disiplin Soruşturmasında Delil ve İspat' (2018) 132 Türkiye Barolar Birliği Dergisi 231, 232; Anayasa Mahkemesi de bir kararında bu hususu şu şekilde açlklamaktadır: "Disiplin cezaları, kamu hizmetlerinin gereği gibi yürütülmesini sağlamak amacıyla öngörülmüş, yapma veya yapmama biçiminde beliren davranış kurallarının ihlali hâlinde uygulanan, yasal olarak düzenlenmiş idari yaptırımlardır. Kamu hizmetlerini yürütenlerin görev, yetki ve sorumlulukları kamu hizmeti ve hizmet gerekleri ile sınırlandırılmış, bu sınırlar dışına çıkanların ise disiplin cezaları ile cezalandirlmaları ilgili kanunlarda öngörülmüş̧ür", Anayasa Mahkemesi, E. 2015/85, K. 2016/3, 13.01.2016.

İbrahim Pınar ve Öner Çalışkan, Açıklamalı-İçtihath Disiplin Suç ve Cezaları ve Disiplin Soruşturması (1. Baskı, Seçkin Yayıncillk 2013) 19.

13 Canoğlu (n 11) 234.

14 Ali D. Ulusoy, Yeni Türk İdare Hukuku (3. Bask1, Yetkin Yayınları 2020) 472.

15 Türk Silahlı Kuvvetleri Disiplin Kanunu, Kanun Numarası: 6143, Kabul Tarihi: 31.1.2013, RG. 16.02.2013/28561.

16 Genel Kolluk Disiplin Hükümleri Hakkında Kanun Hükmünde Kararnamenin Kabul Edilmesine Dair Kanun, Kanun Numarası: 7068, Kabul Tarihi: 31.1.2018, RG. 8.3.2018/30354 (Mük.).

17 Hâkimler ve Savcılar Kanunu, Kanun Numarası: 2802, Kabul Tarihi: 24.2.1983, RG. 26.2.1983/17971.

18 Adlî Yargı İlk Derece Mahkemeleri ile Bölge Adliye Mahkemelerinin Kuruluş, Görev ve Yetkileri Hakkında Kanun, Kanun Numarası: 5235, Kabul Tarihi: 26.9.2004, RG. 7.10.2004/25606.

19 Hâkimler ve Savcilar Kurulu Kanunu, Kanun Numarası: 6087, Kabul Tarihi: 11.12.2010, RG. 18.12.2010/27789.

20 Yargıtay Kanunu, Kanun Numarası: 2797, Kabul Tarihi: 4.2.1983, RG. 8.2.1983/17953; Danıştay Kanunu, Kanun 
Anayasa Mahkemesi üyeleri için Anayasa’nın 140/3 maddesi ile Anayasa Mahkemesinin Kuruluşu ve Yargılama Usulleri Hakkında Kanun'da ${ }^{21}$, Hâkimler ve Savcılar Kurulu üyeleri için; hâkim savcı sınıfından üyeler için Anayasa’nın140/3 maddesinde, Bakan yardımcısı ve seçimle gelen üyelerin tamamı için 6087 sayılı Hâkimler ve Savcılar Kurulu Kanunu’nda, Sayıştay meslek mensupları için 6085 sayılı Sayıştay Kanunu’nda ${ }^{22}$ kurala bağlanmıştır ${ }^{23}$.

Öncelikle, disiplin cezası yaptırımının ne anlama geldiği ortaya koyulduktan sonra bu müeyyidenin suç karşılığında öngörülen yaptırımlardan biri olan cezalardan farkını ortaya koymak gerekecektir. Cezalar, genel olarak toplum düzenini ilgilendiren kurallara uymama sonucunda uygulanan yaptırımlar iken, disiplin cezaları yalnızca belirli bir meslek ya da statü grubunun düzenini bozan fiiller bakımından tatbik edilirler ${ }^{24}$. Buradan da anlaşılacağı üzere cezalar toplumun düzenini sağlamak amacıyla uygulanırken, disiplin cezaları belirli bir meslek ya da statü gruplarının düzenini sağlamak için tatbik edilirler ${ }^{25}$. Dolayısıyla cezaların muhatabı herkes olabilecek iken, disiplin yaptırımlarının muhatabı ancak belirli bir meslek ya da statü sahibi kişiler olabilir ${ }^{26}$. Bu iki yaptırım arasındaki diğer bir farklılık bu yaptırımları uygulayan makamlar yönünden ortaya çıkmaktadır. Cezalara ancak bir iddianame ile açılan davada yapılacak yargılama sonucunda hükmedilebilecek iken, disiplin yaptırımlarına ilgili idari merciiler hükmeder ${ }^{27}$. Disiplin yaptırımlarına hükmetme yetkisinin idareye bırakılması adli makamların yükünü hafifletir ${ }^{28}$. Ayrıca suçlar karşılığında öngörülen cezalar kişi hak ve özgürlüklerini kısıtlayıcı nitelikte olmalarına rağmen, disiplin cezaları yalnızca bazı hak ve yetkilerin kısıtlanması sonucunu doğurur ${ }^{29}$. Burada önemle ifade etmek gerekir ki bir fiilin hem ceza hukuku anlamında suç hem de disiplin suçu teşkil etmesi mümkündür. Bu durumda bu fiili işleyen kişi hakkında hem ceza hem de disiplin yaptırımına hükmetmek olanaklıdır ${ }^{30}$. Bu durum,

Numarası: 2575, Kabul Tarihi: 6.1.1982, RG. 20.1.1982/17580.

21 Anayasa Mahkemesinin Kuruluşu ve Yargılama Usulleri Hakkında Kanun, Kanun Numarası: 6216, Kabul Tarihi: 30.3.2011, RG. 3.4.2011/27894.

22 Sayıştay Kanunu, Kanun Numarası: 6085, Kabul Tarihi: 3.12.2010, RG. 19.12.2010/27790.

23 Yiğit ve Öztürk (n 10) 56 vd.

24 Serkan Çınarlı, 'Yükseköğretim Kurumlarında Disiplin Soruşturması Sorunu ve Alman Disiplin Mahkemeleri Modeli Önerisi’ (2011) 19(1) Selçuk Üniversitesi Hukuk Fakültesi Dergisi 39, 43; Pınar ve Çalışkan (n 12) 41; Çağlayan, İdare Hukuku (n 7) 526; Enver Kaşlı, Polis Disiplin Hukuku (1. Baskı, Adalet Yayınevi 2020) 40.

25 Akyılmaz (n 7) 3; Çağlayan, İdare Hukuku (n 7) 527; Toroslu, Ceza Müeyyidesi (n 9) 20.

26 Cengiz Topel Çiftçioğlu, '2802 Sayılı Hakimler ve Savcılar Kanununa Göre Hakim ve Savcıların Disiplin Soruşturmaları' (2013) 13(1) Dokuz Eylül Üniversitesi Hukuk Fakültesi Dergisi 127, 132.

27 Çağlayan, İdare Hukuku (n 7) 526; Akyılmaz (n 7) 3; Pınar ve Çalışkan (n 12) 41.

28 Toroslu, Ceza Müeyyidesi (n 9) 15.

29 Pınar ve Çalışkan (n 12) 42; Anayasa Mahkemesi de bir kararında bu hususu şu şekilde ifade etmektedir: "Gerek adli gerekse idari suçlarda, davranış normlarına aykırı ve haksızlık teşkil eden bir fiille kanun koyucunun koruma altına aldığ bir hukuki değerin ihlali söz konusu olduğundan her iki suç türü arasında büyük benzerlikler bulunmaktadır. Adli suçlarla idari suçlar arasındaki fark, esas itibarıyla nicelik yönünden olup adli suçlardaki haksızlık içeriği idari suçlara nazaran daha yoğundur. Öte yandan adli suçlar karşıllğında öngörülen yaptırımlar idari suçlardan farklı olarak hürriyeti bağlayıcı cezayı gerektirse de her iki alanda öngörülen yaptırımlar yoğun maddi cebir içermektedir. Bu nedenle Anayasa'nın 38. maddesinde öngörülen ilkelerin idari suçlar yönünden de uygulanması gerekmektedir.", Anayasa Mahkemesi, E. 2018/30, K. 2018/94, 25.09.2018; Benzer açıklamalara yer verilen başka bir karar için bkz. Anayasa Mahkemesi, E. 2015/85, K. 2016/3,13.01.2016.

30 Toroslu, Ceza Müeyyidesi (n 9) 18; Ersan Şen, 'İdari Ceza Hukuku' (1994) (8) İstanbul Üniversitesi Siyasal Bilgiler Fakültesi Dergisi 21, 23. 
bir fiilden dolayı bir kez yargılama ve cezalandırma anlamına gelen non bis in idem ilkesine aykırılık teşkil etmeyecektir ${ }^{31}$.

Disiplin hukukuna hakim olan ilkeler, genellikle yargı içtihatları sonucunda şekillenmiştir ${ }^{32}$. Suç ve cezalara ilişkin temel ilkelerden olan; cezaların şahsiliği ilkesi, kanunilik ilkesi, savunma hakkının verilmesi ilkesi, soruşturmanın gizliliği ilkesi, hukuka aykırı delil yasağı ve bir fiilden dolayı bir kez cezalandırma gibi ilkeler disiplin suç ve cezaları bakımından da geçerlidir ${ }^{33}$. Ancak aşağıda kanunilik ilkesi özelinde ifade edileceği gibi bu ilkelerden bazıları disiplin hukukunda suç ve cezalarda olduğu kadar katı bir şekilde uygulanmaz.

\section{B. YÜKSEKÖĞRETIM ÖĞRENCILERININ DISIPLIN REJIMi}

Eğitim ve öğrenim hakkı Anayasa’nın 42'nci maddesinde düzenlenmektedir ${ }^{34}$. Maddenin ilk fikrasında "Kimse, eğitim ve öğrenim hakkından yoksun bırakılamaz" şeklinde bir hükme yer verilip bu temel hak ve hürriyet bakımından ana ilke ortaya koyulduktan sonra; ikinci fikrada eğitim hakkının kapsamının kanunla tespit edilip düzenleneceği hükme bağlanmıştır. Eğitim hakkı, eğitimöğretim faaliyetlerinin düzenli bir şekilde yürütülmesi için, eğitim kurumlarından çıkarma da dahil olmak üzere çeşitli disiplin tedbirlerine başvurulmasına engel teşkil etmez. Zira disiplin yaptırımları hem öğrencilerin gelişimi hem de eğitim kurumunun amaçlarına ulaşılması noktasında önemli bir vasıtadır ${ }^{35}$. Ancak Anayasa Mahkemesi’nin de bir kararında belirttiği gibi; "eğitim hakkının özüne dokunan ve etkinliğini ortadan kaldıran kısıtlamalardan korunmak için bu kısıtlamaların öngörülebilir olması ve meşru amaç çerçevesinde ölçülü olarak yapılması" gerekmektedir ${ }^{36}$.

31 Ramazan Çağlayan, İdari Ceza Hukuku (1. Baskı, Adalet Yayınevi 2013) 24; Çiftçioğlu (n 26$) 134$.

32 Selman Sacit Boz, 'Memur Disiplin Hukukuna Aykırı Olan Temel İlkeler' (2017) 25(2) Selçuk Üniversitesi Hukuk Fakültesi Dergisi 15, 20.

33 Ulusoy, İdare Hukuku (n 14) 473; Çağlayan, İdare Hukuku (n 7) 527; Canoğlu (n 11) 235-237; Kaşl1 (n 24) 42; Toroslu, Ceza Müeyyidesi (n 9) 15; Şen (n 30) 23; Ümit Güveyi, 'Memur Disiplin Hukukunda Mobbing' (2013) 17(1-2) Gazi Üniversitesi Hukuk Fakültesi Dergisi 1455, 1468; Çiftçioğlu (n 26) 133.

34 Eğitim ve Öğrenim Hakkı ve Ödevi başlı̆̆ını taşıyan maddenin tam hâli şu şekildedir: "Kimse, eğitim ve öğrenim hakkından yoksun bırakılamaz. Öğrenim hakkının kapsamı kanunla tespit edilir ve düzenlenir. Eğitim ve öğretim, Atatürk ilkeleri ve inkılâpları doğrultusunda, çă̆daş bilim ve eğitim esaslarına göre, Devletin gözetim ve denetimi altında yapılır. Bu esaslara aykırı eğitim ve öğretim yerleri açılamaz. Ĕ̆itim ve öğretim hürriyeti, Anayasaya sadakat borcunu ortadan kaldırmaz. İlköğretim, kız ve erkek bütün vatandaşlar için zorunludur ve Devlet okullarında parasızdır. Özel ilk ve orta dereceli okulların bağlı olduğu esaslar, Devlet okulları ile erişilmek istenen seviyeye uygun olarak, kanunla düzenlenir. Devlet, maddî imkânlardan yoksun başarılı öğrencilerin, öğrenimlerini sürdürebilmeleri amacı ile burslar ve başka yollarla gerekli yardımları yapar. Devlet, durumları sebebiyle özel eğitime ihtiyacı olanları topluma yararlı kılacak tedbirleri alır. Eğitim ve öğretim kurumlarında sadece eğitim, öğretim, araştırma ve inceleme ile ilgili faaliyetler yürütülür. Bu faaliyetler her ne suretle olursa olsun engellenemez. Türkçeden başka hiçbir dil, eğitim ve öğretim kurumlarında Türk vatandaşlarına ana dilleri olarak okutulamaz ve ögretilemez. Eğitim ve öğretim kurumlarında okutulacak yabancı diller ile yabancı dille eğitim ve ögretim yapan okulların tabi olacağı esaslar kanunla düzenlenir. Milletlerarası andlaşma hükümleri saklıdır."

35 Anayasa Mahkemesi, Başvuru No: 2014/5881, 15.02.2017: "Eğitim hakkı, esas itibarıla kurallara uyulmasımı sağlamak amacıyla bir eğitim kurumundan uzaklaştırma veya çıkarma da dâhil olmak üzere disiplin tedbirlerine başvurmayı engellemez. Şüphesiz disiplin cezaları, gerek öğrencilerin gelişiminin gerekse de bir okulun amaçlarına ulaşmasın sağlayacak araçların önemli bir parçasıdır."

36 Anayasa Mahkemesi, Başvuru No: 2013/583, 10.12.2014. 
Yükseköğretim kurumlarında eğitim-öğretim gören öğrenciler için öngörülen disiplin suç ve cezaları, 2547 sayılı Yükseköğretim Kanunu’nun 54 ve 65 ’inci maddeleri ile Yükseköğretim Kurumları Öğrenci Disiplin Yönetmeliği'nde düzenlenmiştir.

Anayasanın “yükseköğretim kurumları” başlı̆̆ını taşıyan 130'uncu maddesinin dokuzuncu fikrasında yer alan "Yükseköğretim kurumlarının kuruluş ve organları ile işleyişleri ve bunların seçimleri, görev, yetki ve sorumlulukları üniversiteler üzerinde Devletin gözetim ve denetim hakkını kullanma usulleri, öğretim elemanlarının görevleri, unvanları, atama, yükselme ve emeklilikleri, öğretim elemanı yetiştirme, üniversitelerin ve öğretim elemanlarının kamu kuruluşları ve diğer kurumlar ile ilişkileri, öğretim düzeyleri ve süreleri, yükseköğretime giriş, devam ve alınacak harçlar, Devletin yapacağ yardımlar ile ilgili ilkeler, disiplin ve ceza işleri, mali işler, özlük hakları, öğretim elemanlarının uyacakları koşullar, üniversitelerarası ihtiyaçlara göre öğretim elemanlarının görevlendirilmesi, öğrenimin ve ögretimin hürriyet ve teminat içinde ve çağdaş bilim ve teknoloji gereklerine göre yürütülmesi, Yükseköğretim kuruluna ve üniversitelere Devletin sağladığı mali kaynakların kullanılması kanunla düzenlenir.” hükmü uyarınca disiplin işlerinin kanunla düzenlenmesi gerekmektedir. Madde metninde kanunla düzenlenecek disiplin işlerinin, öğrencilere mi yoksa yükseköğretim kurumlarında görevli öğretim elemanları ya da idari personel mi yönelik olduğu hususu açık değildir. Benzer şekilde Anayasa gerekçesinde de bu konuda bir açıklama yer almamaktadır. Ancak, anılan madde metninde "disiplin ve ceza işleri” ibaresinden önce yer alan ve kanunla düzenlenecek hususlar arasında sayılan "yükseköğretime giriş, devam ve alınacak harçlar"ın öğretim elemanları ya da idari personel için değil yükseköğrenim gören öğrenciler için söz konusu olduğu dikkate alındığında, madde metninde yer alan ve kanunla düzenlenecek olan disiplin işlerini “öğrenci” disiplin işleri şeklinde anlamak daha uygundur. Kaldı ki disiplin işlerinin madde metninde zikredilen öğretim elemanlarını ya da idari personeli de kapsadığı şeklinde yapılacak bir yorum ${ }^{37}$ öğrencilerin kapsam dişında tutulduğu yönünde bir sonuç doğurmayacak, disiplin işlerine müteallik kanunilik ilkesinin öğrenciler bakımından da geçerli olduğu şeklinde bir neticeye ulaşmayı engellemeyecektir. Madde metninde yer alan kanunla düzenlenmesi gerekli disiplin işleri kapsamına “öğrencileri” dahil etmeyecekşekilde yapılacak katı bir yorum ise maddenin lafzına ve ruhuna uygunluk taşımayacaktır. Doktrinde vergi, resim ve harçlar bakımından kanunilik ilkesine dayanak olarak gösterilen Anayasảnın 73'üncü maddesinin 3'üncü fikrasında yer alan "Vergi, resim, harç ve benzeri mali yükümlülükler kanunla konulur, değisstirilir veya kaldırılır” hükmünün dışında, yükseköğretim hizmeti karşılığında harç alınması durumunda, alınacak olan bu harçlar için Anayasảnın

37 Kamu hizmeti görevlileriyle ilgili hükümleri düzenleyen Anayasảnın "Genel ilkeler" başlıklı 128/2 maddesinde yer alan "Memurların ve diğer kamu görevlilerinin nitelikleri, atanmaları, görev ve yetkileri, hakları ve yükümlülükleri, aylı ve ödenekleri ve diğer özlük işleri kanunla düzenlenir" hükmü ile "Görev ve sorumluluklarl, disiplin kovuşturulmasında güvence" başlıkl 129/2-3 maddesinde yer alan; "Memurlar ve diğer kamu görevlileri ile kamu kurumu niteliğindeki meslek kuruluşları ve bunların üst kuruluşları mensuplarına savunma hakkı tanınmadıkça disiplin cezası verilemez. Disiplin kararları yargı denetimi dışında bırakılamaz." hükmüyle, yükseköğretim kurumlarında görevli öğretim elemanları ve idari personeli de içerecek şekilde, memurların ve diğer kamu görevlilerinin disiplin işlerinin kanunla düzenlenmesi gerektiği ile disiplin işlerine ilişkin esaslar kurala bağlanmıştır. Bu durumda, Anayasảnın 130/9 maddesinin yükseköğretim kurumlarında görevli öğretim elemanları ve idari personelinin disiplin işlemlerini de kapsayacak şekilde ikinci bir kez hüküm sevk ettiğinden bahsetmede hukuki isabet bulunmamaktadır. Nitekim, Anayasa Mahkemesi kararlarında ve doktrinde de memurlar ve diğer kamu görevlilerinin disiplin işlerinin kanunla düzenlenmesi gereğine dayanak olarak Anayasảnın 128'inci maddesinin ikinci fikrasında yer alan “diğer özlük işleri” ibaresi gösterilmektedir. Buna karşıllık, madde metinlerinden anlaşılacağı üzere, yükseköğretim öğrenci disiplin işlerine kanuni dayanak olarak Anayasảnın 128 ve 129 'uncu maddelerini göstermeye imkân yoktur. Bu nedenle de öğrenci disiplin işlerinin kanunla düzenlenmesi zorunluluğunun Anayasal dayanağının 38'inci maddenin yanı sıra 130'uncu madde olarak kabulü bir başka gerekliliktir. 
130'uncu maddesinde yer alan "alınacak harçlar... kanunla düzenlenir" hükmünün de "kanunilik" ilkesine dayanak olarak gösterileceği yönünde görüşler bulunmaktadır ${ }^{38}$. Buradan hareketle Anayasa’nın 130’uncu maddesinde yer alan alınacak harçların kanunla düzenleneceği hükmü açıkça “öğrencilerden alınacak haçlar” şeklinde öğrenci vurgusu yapmadı̆̆ı halde sistematik bir yorumla bunun yükseköğretimden yararlanan öğrencilerden alınan harçlar bakımından kanunilik ilkesine dayanak olarak kabulü, disiplin işlerinin kanunla düzenleneceği ibaresinin de “öğrenci disiplin işleri” şeklinde açık bir öğrenci vurgusu taşımasa da yükseköğretimden yararlanan öğrencilerin disiplin işlerinin kanunla düzenlenmesi gereğinin Anayasal dayanağının 130'uncu madde olduğu yönünde bir neticeye varmak mümkündür. Bu itibarla, 2547 sayılı Yükseköğretim Kanunu’nun 54 ve 65 'inci maddelerinde yer alan yükseköğretim kurumlarında eğitim-öğretim gören öğrenciler için öngörülen disiplin suç ve cezalarına ilişkin kanun düzenlemelerinin, daha açık bir ifade ile yükseköğretim öğrencilerinin disiplin rejimine esas kanunilik ilkesinin Anayasanın 130’uncu maddesinin dokuzuncu fikrasında dayanak bulduğunu söylemek mümkündür.

Yükseköğretim Kanunu’nun 54'üncü maddesinin (a) bendinde aynen şu hükme yer verilmektedir: "Yükseköğretim kurumları içinde veya dışında yükseköğretim öğrenciliği sıfatına, onur ve şerefine aykırı harekette bulunan, öğrenme ve öğretme hürriyetini, doğrudan doğruya veya dolayl olarak kısıtlayan, kurumların sükûn, huzur ve çalışma düzenini bozan, boykot, işgal ve engelleme gibi eylemlere katılan, bunları teşvik ve tahrik eden, yükseköğretim mensuplarının şeref ve haysiyetine veya şahıslarına tecavüz eden veya saygı dışı davranışlarda bulunan ve anarşik veya ideolojik olaylara katılan veya bu olayları tahrik ve teşvik eden öğrencilere; eylem başka bir suçu oluştursa bile ayrıca uyarma, kınama, bir haftadan bir aya kadar veya bir veya iki yarıyıl için kurumdan uzaklaştırma veya yükseköğretim kurumundan çıkarma cezaları verilir." Görüldüğü üzere ilgili düzenlemede yükseköğretim kurumlarında öğrenci olan kişiler için öngörülen disiplin suç ve cezalarına yer verilmiştir. Bu düzenleme yapılırken her fiil karşılığında öngörülen disiplin cezalarına ayrı ayrı yer verilmeyip, disiplin suç ve cezaları toplu halde sayılmıştır. Ayrıca bu fiillerin yükseköğretim kurumları içinde ya da dışında işlenmesi noktasında da herhangi bir ayrıma gidilmemiştir. Buna göre, yükseköğretim kurumları öğrencileri için öngörülen disiplin suçları şu şekildedir:

- Yükseköğretim öğrenciliği sıfatına, onur ve şerefine aykırı harekette bulunmak,

- Öğrenme ve öğretme hürriyetini, doğrudan doğruya veya dolaylı olarak kısıtlamak,

- Kurumların sükûn, huzur ve çalışma düzenini bozmak,

- Boykot, işgal ve engelleme gibi eylemlere katılmak, bunları teşvik ve tahrik etmek,

- Yükseköğretim mensuplarının şeref ve haysiyetine veya şahıslarına tecavüz etmek veya saygı dışı davranışlarda bulunmak,

- $\quad$ Anarşik veya ideolojik olaylara katılmak veya bu olayları tahrik ve teşvik etmek.

Bu fiiller karşılığında öngörülen disiplin cezaları ise; uyarma, kınama, bir haftadan bir aya kadar veya bir veya iki yarıyıl için kurumdan uzaklaştırma ve yükseköğretim kurumundan çıkarma cezalarıdır. Bu fiillerin başka bir suç oluşturması disiplin cezası vermeye engel teşkil etmeyecektir ${ }^{39}$.

38 Mustafa Umur Tosun ve İlhami Öztürk, 'Yükseköğretim Hizmeti Karşılığında Devlet ve Vakıf Yükseköğretim Kurumlarına Yapılan Ödemelerin Hukuki Niteliği' (2017) 13(148) Legal Mali Hukuk Dergisi 765, 792-793. 
Maddenin (b) bendinde, öğrencilerin işlemiş oldukları disiplin suçlarından dolayı soruşturma yapmaya veya disiplin cezası vermeye yetkili kurul ve makamlar belirtilmiştir ${ }^{40}$. Maddenin (c) bendinde, disiplin soruşturmasına ne zaman başlanacağı ve hangi süre içerisinde tamamlanacağı düzenleme altına alınmıştır ${ }^{41}$. Maddenin (d) bendinde hakkında disiplin soruşturması yapılacak öğrenciye savunma hakkının verilmesi ${ }^{42}$, (e), (f) ve (g) bentlerinde ise verilen disiplin cezasının öğrenciye ve diğer ilgili kurum ve kuruluşlara tebliğ edilmesi ile ilgili usul ve esaslara yer verilmiştir ${ }^{43}$.

Yükseköğretim Kanunu'nun Yükseköğretim Kurulu tarafından çıkarılacak yönetmelikleri düzenleyen 65'inci maddesinde yer alan; “Öğretim elemanları, memur ve diğer personel ile öğrencilerin disiplin işlemleri, disiplin amirlerinin yetkileri ve disiplin kurullarının teşkili ve çalışması ile ilgili hususlar"ın Yükseköğretim Kurulu tarafından çıkarılacak yönetmeliklerle düzenleneceği hüküm altına alınmıştır. Bu kapsamda Yükseköğretim Kanunu’nun 54 ve 65’inci maddelerine dayanılarak ilk olarak 13/01/1985 tarihli ve 18634 sayılı Resmi Gazetede yayımlanarak yürürlüğe giren Yükseköğretim Kurumları Öğrenci Disiplin Yönetmeliği kabul edilerek uzun süre uygulanmıştır. 18/08/2012 tarihli ve 28388 sayılı Resmi Gazetede yayımlanarak yürürlüğe giren Yükseköğretim Kurumları Öğrenci Disiplin Yönetmeliği, önceki yönetmeliği yürürlükten kaldırmış ve uygulanmaya başlamıştır ${ }^{44}$. Bu yönetmeliğin yürürlüğe girdiği tarihten önce soruşturmasına başlanmış ancak tamamlanmamış bulunan disiplin suçları bakımından bu yönetmelik düzenlemeleri uygulanmıştır ${ }^{45}$. Bu yönetmeliğin ilk üç maddesinde amaç, kapsam ve dayanak hükümlerine yer verildikten sonra, 4 ila 10’uncu maddeleri arasında yükseköğretim öğrencileri için disiplin suçu teşkil eden fiiller ile bu fiiller karşılığında öngörülen; uyarma ${ }^{46}$, kınama $^{47}$, yükseköğretim kurumundan bir haftadan bir aya

40 MADDE 54/b: "Bir fakülte, enstitü veya yüksekokulun içinde veya dışında öğrencilerin işlemiş oldukları disiplin suçlarından dolayı soruşturma yapmaya ve doğrudan gerekli cezayı vermeye veya disiplin kuruluna sevk etmeye ilgili fakülte dekanı, enstitü veya yüksekokul müdürü yetkilidir."

41 MADDE 54/c: "Disiplin soruşturmasına, olay öğrenilince derhal başlanılır ve soruşturma en geç on beş gün içinde sonuçlandırılır."

42 MADDE 54/d: "Hakkında kovuşturma yapılan öğrenciye sözlü veya yazılı savunma hakkı verilir. Tanınan süre içinde savunma yapmayan öğrenci bu hakkından vazgeçmiş sayılır."

43 MADDE 54/e: "Disiplin cezaları, ilgili öğrenciye yazı ile bildirilir. Durum, öğrenciye burs veya kredi veren kuruluşa ve Yükseköğretim Kuruluna duyurulur. Yükseköğretim kurumundan çıkarma kararlarına karşı on beş gün içinde üniversite yönetim kuruluna itiraz edilebilir. Cezalar öğrencinin dosyasına ve siciline işlenir.”

MADDE 54/f: "Bu maddeye göre yapılacak işlemler sırasında gerekirse öğrenciye, bağlı bulunduğu öğretim kuruluşunda, ilan yoluyla tebligat yapilabilir."

MADDE 54/g: "Yükseköğretim kurumundan çıkarma kararı bütün yükseköğretim kurumlarına, Yükseköğretim Kurulu, emniyet makamları ve ilgili askerlik şubelerine bildirilir."

44 İki yönetmelik arasındaki farklılıklar konusunda detaylı bilgi için bkz. Pınar ve Çalışkan (n 12) 788-789.

45 GEÇİCI MADDE 1: “Bu yönetmeliğin yürürlüğe girdiği tarihten önce soruşturmasına başlanmış ancak tamamlanmamış bulunan disiplin soruşturmalarında bu Yönetmelik hükümleri uygulanır”

46 MADDE 4 :"(1) Uyarma cezasını gerektiren eylemler şunlardır; a) Yükseköğretim kurumu yetkililerince sorulan hususları haklı bir sebep olmadan zamanında cevaplandırmamak, b) Yükseköğretim kurumu yetkililerince tespit edilen yerler dışında ilan asmak, c) Yükseköğretim kurumunun izniyle asılmış duyuruları, program ve benzerlerini koparmak, yırtmak, değiştirmek, karalamak veya kirletmek.”

47 MADDE 5: “(1) Kınama cezasını gerektiren eylemler şunlardır; a) Yükseköğretim kurumu yetkililerince istenilen bilgileri eksik veya yanlış bildirmek, b) Ders, seminer, uygulama, laboratuvar, atölye çalışması, bilimsel toplantı ve konferans gibi çalışmaların düzenini bozmak, c) Yükseköğretim kurumu içinde izinsiz olarak bildiri dağıtmak, afiş ve pankart asmak, ç) 
kadar uzaklaştırma ${ }^{48}$, yükseköğretim kurumundan bir yarıyıl için uzaklaştırma ${ }^{49}$, yükseköğretim kurumundan iki yarıyıl için uzaklaştırma ${ }^{50}$ ve yükseköğretim kurumundan çıkarma ${ }^{51}$ cezalarına ayrıntılı olarak yer verilmiştir. Görüldüğü üzere, yükseköğretim kurumlarındaki öğrenciler için öngörülen disiplin cezalarının hangi fiiller karşılığında tatbik edileceği yönetmelikle düzenlenmiştir. Kanun koyucu, yükseköğretim kurumlarındaki öğrencilerin disiplin rejiminin kamu görevlileri için geçerli olan disiplin rejimini düzenleyen DMK’nın 125'inci maddesinde olduğu gibi kanunla düzenlemek yerine yönetmeliğe bırakmayı tercih etmiştir. Burada önce disiplin hukukunda da geçerli olan suçta ve cezada kanunilik ilkesi ve bu ilkenin disiplin hukukundaki yansımasına değinilecek, ardından ise yükseköğretim kurumu öğrencileri için öngörülen bu disiplin rejiminin suçta ve cezada kanunilik ilkesine uygunluğu Anayasa Mahkemesi kararları ışı̆̆ında irdelenecektir.

Yükseköğretim kurumunca asılmış duyuruları, program ve benzerlerini koparmak, yırtmak, değiştirmek, karalamak veya kirletmek, d) Sinavlarda kopyaya teșebbüs etmek."

48 MADDE 6: "(1) Yükseköğretim kurumundan bir haftadan bir aya kadar uzaklaștırma cezasını gerektiren eylemler şunlardır; a) Öğrenme ve öğretme hürriyetini engelleyici veya yükseköğretim kurumlarının işleyiş ve huzurunu bozucu eylemlerde bulunmak, b) Disiplin soruşturmalarının sağlkkl bir şekilde yürütülmesini engellemek, c) Yükseköğretim kurumundan aldığ kendine hak sağlayan bir belgeyi başkasına vererek kullandırmak veya başkasına ait bir belgeyi kullanmak, ç) Yükseköğretim kurumunda kişilerin şeref ve haysiyetini zedeleyen sözlü veya yazıl eylemlerde bulunmak, d) Yükseköğretim kurumu personelinin, kurum içinde ya da dışında, șeref ve haysiyetini zedeleyen sözlü veya yazll eylemlerde bulunmak, e) Yükseköğretim kurumunda alkollü içki içmek, f) Yükseköğretim kurumuna ait kapalı ve açık mahallerde yetkililerden izin almadan toplantılar düzenlemek."

49 MADDE 7: “(1) Yükseköğretim kurumundan bir yarıyl için uzaklaştırma cezasını gerektiren eylemler şunlardır; a) Yükseköğretim kurumu personeli ve öğrencilerini tehdit etmek, b) Yükseköğretim kurumlarında işgal ve benzeri fillerle yükseköğretim kurumunun hizmetlerini engelleyici eylemlerde bulunmak, c) Kurum personeli ve öğrencilerine fiili saldırıda bulunmak, ç) Yükseköğretim kurumlarında hırsızlk yapmak, d) Yükseköğretim kurumu bünyesinde mevcut bina, demirbaş eşya ve benzeri malzemeyi tahrip etmek veya bilişim sistemine zarar vermek, e) Sinavlarda kopya çekmek veya çektirmek, $f$ ) Seminer, tez ve yayınlarında intihal yapmak. g) Yükseköğretim kurumundan uzaklaştırma cezası almış olmasına rağmen, bu karara uymamak."

50 MADDE 8: “(1) Yükseköğretim kurumundan iki yarıyıl için uzaklaştırma cezasını gerektiren eylemler şunlardır; a) Yükseköğretim kurumu görevlilerine karşı cebir ve şiddet kullanarak görevin yapılmasına engel olmak, b) Öğrencilere karşı cebir ve şiddet kullanarak yükseköğretim hizmetlerinden yararlanmaların engellemek, c) Suç sayılan eylemleri işlemek veya bir kimseyi veya grubu, cebir veya tehditle suç sayılan bir eylemi düzenlemeye veya böyle bir eyleme katılmaya zorlamak, c) Yükseköğretim kurumları içerisinde uyuşturucu ve uyarıcı madde kullanmak, tașımak, bulundurmak, d) Sinavlarda tehditle kopya çekmek, kopya çeken öğrencilerin sınav salonundan çıkarılmasına engel olmak, kendi yerine başkasını sınava sokmak veya başkasının yerine sinava girmek, e) Yükseköğretim kurumlarında cinsel tacizde bulunmak, f) Yükseköğretim kurumlarında 10/7/1953 tarihli ve 6136 saylı Ateşli Silahlar ve Bıçaklar ile Diğer Aletler Hakkında Kanuna aykırı olarak ateşli silahlarla mermilerini ve bıçaklarla saldırı ve savunmada kullamılmak üzere özel olarak yapılmış bulunan diğer aletleri, patlayıcı maddeleri taşımak ve bulundurmak, g) Yükseköğretim kurumunun bilişim sistemine girerek kendisine veya başkasının yararına haksız bir çıkar sağlamak, ğ)Soruşturma ile görevlendirilenleri tehdit etmek."

51 MADDE 9: "(1) Yükseköğretim kurumundan çıkarma cezasını gerektiren eylemler şunlardır; a) Mahkeme kararıla kesinleşmiş olmak kaydryla, suç işlemek amactyla örgüt kurmak, böyle bir örgütü yönetmek veya bu amaçla kurulan örgüte üye olmak, üye olmamakla birlikte örgüt adına faaliyette bulunmak veya yardım etmek, b) Yükseköğretim kurumlarında uyuşturucu veya uyarıcı maddeleri satmak, satın almak, başkalarına vermek ve ticaretini yapmak, c) 6136 sayılı Ateşli Silahlar ve Bıçaklar ile Diğer Aletler Hakkında Kanuna aykırı olarak ateşli silahlarla, mermilerini ve bıçaklarla saldırı ve savunmada kullanılmak üzere özel olarak yapılmış bulunan diğer aletleri, patlayıcı maddeleri kullanmak, ç) Kişilerin vücudu üzerinde cinsel davranışlarda bulunmak suretiyle cinsel dokunulmazlikların ihlal etmek." 


\section{SUÇTA VE CEZADA KANUNILIK íkesi VE BU íKENIN DisípLIN HUKUKUNDAKI YANSIMASI}

\section{A. SUÇTA VE CEZADA KANUNILIK ILKESi}

Suçta ve cezada kanunilik ilkesi en genel tanımıyla, suçların ve suçlar karşılı̆̆ında öngörülen yaptırımların yalnızca kanunla ihdas edilebilmesini ifade etmektedir ${ }^{52}$. Bu ilke sonucunda kanunun açıkça suç saymadığı bir fiilden dolayı kimse cezalandırılamayacak ve suç teşkil eden fiil karşılığında bir kimse hakkında kanunda yazılandan fazla cezaya hükmedilemeyecektir ${ }^{53}$. Suçta ve cezada kanunilik ilkesi ceza hukukunun evrensel ilkelerinden biridir ${ }^{54}$. Bu ilke ayrıca, hukuk devleti ilkesi ile onun bir uzantısı olan hukuki güvenlik ilkelerinin de temellerinden birisini oluşturmaktadır ${ }^{55}$.

Suçta ve cezada kanunilik ilkesi, Avrupa İnsan Hakları Sözleşmesi’nin (AİHS) 7’nci maddesinde "Hiç kimse, işlendiği zaman ulusal veya uluslararası hukuka göre suç oluşturmayan bir eylem veya ihmalden dolayı suçlu bulunamaz. Aynı biçimde, suçun işlendiği sırada uygulanabilir olan cezadan daha ağır bir ceza verilemez" denilmek suretiyle açıkça düzenlenmiştir ${ }^{56}$. Ayrıca AİHS uyarınca kurulan ve sözleşmeye taraf devletlerin yargılama yetkisini kabul ettiği Avrupa İnsan Hakları Mahkemesi (AİHM) de verdiği kararlarında suçta ve cezada kanunilik ilkesinin önemini sıklıkla vurgulamaktadir ${ }^{57}$. Bu ilkeye ayrıca, İnsan Hakları Evrensel Bildirgesinin de 11'inci maddesinin ikinci fıkrasında "Hiç kimse işlendikleri sırada milli veya milletlerarası hukuka göre suç teşkil etmeyen fiillerden veya ihmallerden ötürü mahkum edilemez. Bunun gibi, suçun işlendiği sırada uygulanabilecek olan cezadan daha şiddetli bir ceza verilemez ${ }^{\prime 58}$ denilmek suretiyle yer verilmiştir.

52 Sulhi Dönmezer ve Sahir Erman, Nazari ve Tatbiki Ceza Hukuku Cilt I (14. Bası, Der Yayınları 2016) 21; Nur Centel, Hamide Zafer ve Özlem Çakmut, Türk Ceza Hukukuna Giriş (8. Bası, İstanbul, Beta Yayınları 2014) 45; Faruk Erem, Ümanist Doktrin Açısından Türk Ceza Hukuku Cilt: I Genel Hükümler (8. Baskı, Ankara Üniversitesi Hukuk Fakültesi Yayınlar1 1968) 68.

53 Erem (n 52) 69; Centel, Zafer ve Çakmut (n 52) 46; Abdullah Batuhan Baytaz, Kanunilik İlkesi Bağlamında Ceza ve Ceza Muhakemesi Hukukunda Yorum (1. Baskı, On İki Levha Yayıncıllk 2018) 8.

54 Ekrem Çetintürk, 'Anayasa Mahkemesi Kararları Iş̧ı̆ında İdarenin Düzenleyici İşlemleriyle Suç ve Ceza Konulamaz İlkesi' (2017) 5(9) Uyuşmazlık Mahkemesi Dergisi 39, 42.

55 Bahri Öztürk ve Mustafa Ruhan Erdem, Uygulamalı Ceza Hukuku ve Güvenlik Tedbiri Hukuku (20. Baskı, Seçkin Yayıncllık 2020) 41-42; Veli Özer Özbek, Koray Doğan ve Pınar Bacaksız, Türk Ceza Hukuku Genel Hükümler (11. Baskı, Seçkin Yayıncılık 2020) 65-66; Hakan Hakeri, Ceza Hukuku Genel Hükümler (22. Baskı, Adalet Yayınevi 2019) 12; Kanunilik ilkesi kabahatler hukuku bakımından da geçerli bir ilke olmakla beraber, Kabahatler Kanunu’nun Kanunilik İlkesi başlıklı 4’üncü maddesinde yer verilen “(1) Hangi fiillerin kabahat oluşturduğu, kanunda açıkça tanımlanabileceği gibi; kanunun kapsam ve koşulları bakımından belirlediği çerçeve hükmün içeriği, idarenin genel ve düzenleyici işlemleriyle de doldurulabilir. (2) Kabahat karşıllğı olan yaptırımların türü̈, süresi ve miktarı, ancak kanunla belirlenebilir" hükmünden de anlaşılacağı üzere, bu ilke kabahatler karşıllı̆ında uygulanacak yaptırımlar bakımından mutlak bir şekilde uygulanacak iken kapsamının kanunla ortaya koyulması şartıyla kabahat teşkil eden fiillerin belirlenmesi noktasında idareye takdir yetkisi tanınmıştır. Bkz. Özbek, Doğan ve Bacaksız (n 55) 51; Berrin Akbulut, Ceza Hukuku Genel Hükümler (6. Baskı, Adalet Yayınevi 2019) 94; Timur Demirbaş, Ceza Hukuku Genel Hükümler (15. Baskı, Seçkin Yayıncılık 2020) 251.

Dönmezer ve Erman (n 52) 38; Özbek, Doğan ve Bacaksız (n 55) 68.

57 "Mahkemenin bir sanığın kovuşturulmasına ve mahkûm edilmesine yol açan eylemi işlediği sırada, söz konusu eylemi cezalandırlabilir kılan bir kanun hükmünün yürürlükte olduğunu ve verilen cezanın söz konusu hükümle getirilen sinırlar aşmadığını teyit etmesi gerekmektedir.", Del Río Prada v İspanya, App no 42750/09, (ECtHR, 21 October 2013) par. 80.

58 İnsan Hakları Evrensel Bildirgesi tam metni için bkz. <https://www.tbmm.gov.tr/komisyon/insanhaklari/pdf01/203- 
Suçta ve cezada kanunilik ilkesine Türkiye’nin de taraf olduğu uluslararası sözleşmelerin yanı sıra, ulusal hukukumuzda yer verilmiştir. Anayasa'nın Suç ve cezalara ilişkin esaslar başlıklı 38'inci maddesinin birinci fikrasında "Kimse, işlendiği zaman yürürlükte bulunan kanunun suç saymadiğ bir fiilden dolayı cezalandırılamaz; kimseye suçu işlediği zaman kanunda o suç için konulmuş olan cezadan daha ă̆ır bir ceza verilemez" denilmek suretiyle suçların kanuniliği ilkesi, aynı maddenin üçüncü fikrasında ise "Ceza ve ceza yerine geçen güvenlik tedbirleri ancak kanunla konulur" denilmek suretiyle cezaların kanuniliği ilkesi hükme bağlanmıştır ${ }^{59}$. Bu ilke ayrıca Türk Ceza Kanunu’nun ${ }^{60}$ (TCK) ikinci maddesinde de düzenlenmiştir. Maddenin ilk fikrasında "Kanunun açıkça suç saymadığ bir fiil için kimseye ceza verilemez ve güvenlik tedbiri uygulanamaz. Kanunda yazıl cezalardan ve güvenlik tedbirlerinden başka bir ceza ve güvenlik tedbirine hükmolunamaz" denilmek suretiyle hem suçların kanuniliği hem de cezaların kanuniliği ilkesi düzenlenmiş bulunmaktadır.

Suçta ve cezada kanunilik ilkesinin benimsenmesiyle kişilerin keyfi olarak cezalandırılmasını engellemek suretiyle onların hak ve hürriyetlerini korumak amaçlanmaktadır ${ }^{61}$. Bu bakımdan bu ilke devletin cezalandırma yetkisini sınırlandırıcı bir etki doğurur ${ }^{62}$. Bireyin fiili yasada suç olarak öngörülen düzenlemenin unsurlarını taşımıyor ise hakim tarafından cezalandırılamayacaktır ${ }^{63}$. Bu ilkeyle ayrıca kişi hangi fiillerinin suç teşkil edebileceğini önceden bilecek ve davranışlarını ona göre yönlendirecektir ${ }^{64}$.

Suçta ve cezada kanunilik ilkesi ceza kanunlarının uygulanması noktasında bazı sonuçlar doğurmaktadır. Bu sonuçlar; belirlilik ilkesi, idarenin düzenleyici işlemleriyle suç ve ceza ihdas edilememesi, geriye yürüme yasağı, kıyas yasağı, örf ve adet hukukunun ceza hukukunda doğrudan kaynak olamaması şeklinde ifade edilebilir.

\section{BELIRLILIK ILKESI}

Belirlilik ilkesi suç ve ceza içeren kanun normunun, tüm bireyler tarafından rahatlıkla anlaşılabilecek şekilde açık ve net olarak düzenlenmesi gerektiği anlamına gelmektedir ${ }^{65}$. Nitekim bu husus TCK'nın 2’nci maddesinin ikinci fıkrasında da suç sayılan fiillerin "açıkça” kaleme alınması gerektiği şeklinde ifade edilmiştir ${ }^{66}$. Suç ve ceza içeren kanun düzenlemesinde açıklamalar öyle iyi yapılmalıdır ki birey,

208.pdf>, Erişim Tarihi 24 Mart 2021.

59 Nevzat Toroslu, Ceza Hukuku Genel Kısım (19. Baskı, Savaş Yayınevi 2013) 41.

60 Türk Ceza Kanunu, Kanun Numarasi: 5237, Kabul Tarihi: 26.09.2004, RG. 12.10.2004/25611.

61 Demirbaş (n 55)116; Bu husus Anayasa Mahkemesi kararlarında da vurgulanmaktadır: "Suçta ve cezada kanunilik ilkesi, hukuk devletinin kurucu unsurlarındandır. Kanunilik ilkesi, genel olarak bütün hak ve özgürlüklerin düzenlenmesinde temel bir güvence oluşturmanin yanı sıra suç ve cezaların belirlenmesi bakımından özel bir anlam ve öneme sahip olup bu kapsamda kişilerin kanunen yasaklanmamış veya yaptırıma bağlanmamıs fiiller dolayısılla keyfî bir şekilde suçlanmaları ve cezalandırılmaları önlenmekte; buna ek olarak suçlanan kişinin lehine olan düzenlemelerin geriye etkili olarak uygulanması sağlanmaktadrr.", Anayasa Mahkemesi, Karlis A.Ş Başvurusu, 2013/849, 15.04.2014, par. 32.

62 Akbulut (n 55) 98.

63 Centel, Zafer ve Çakmut (n 52) 45-46.

64 Mustafa Özen, Ceza Hukuku Genel Hükümler Dersleri (3. Baskı, Adalet Yayınevi 2019) 71.

65 Öztürk ve Erdem (n 55) 45; Centel, Zafer ve Çakmut (n 52) 55.

66 Baytaz (n 53) 72. 
hangi eylemlerinin suç teşkil ettiğini hangilerinin ise suç oluşturmadığını önceden bilmelidir ${ }^{67}$. Görüleceği üzere bu ilke kanun koyucu makama yani yasama organına bir yükümlülük yüklemektedir. Buna göre yasama organı ceza kanunları ihdas ederken açık ve sade bir dil kullanmalı, hükümlerin yorumlanmasında karışıklığa sebebiyet verecek ibarelerden kaçınmalıdır.

\section{IDARENIN DÜZENLEYICI işLEMLERIYLE SUÇ VE CEZA IHDAS EDILEMEMESi}

Kanunilik ilkesinin bir diğer sonucu, idarenin düzenleyici işlemleriyle suç ve ceza ihdas edilememesidir ${ }^{68}$. Bu ilkeye Anayasa'da açıkça yer verilmemiş olsa da TCK'nın 2'nci maddesinin ikinci fikrasında "İdarenin düzenleyici işlemleriyle suç ve ceza konulamaz" denilmek suretiyle bu kural ortaya koyulmuştur ${ }^{69}$.

Bu kurala göre; cumhurbaşkanlığı kararnamesi, yönetmelik, tüzük ve genelge gibi idare tarafından çıarılan düzenleyici işlemler ile suç ve ceza öngörülmesi mümkün değildir ${ }^{70}$. Dolayısıyla, ceza hukukunda "açık hüküm", "beyaz hüküm” veya "açık ya da beyaz ceza normu” olarak ifade edilen, suçun çerçevesinin kanun hükmüyle çizildiği ancak içeriğinin idare tarafından belirlenmesi usulüne $\mathrm{f}^{71}$ başvurmak mümkün değildir ${ }^{72}$.

\section{GERIYE YÜRÜME YASAĞI}

Kanunilik ilkesinin bir diğer sonucu olan geriye yürüme yasağı, suç teşkil eden fiile, fiilin işlendiği zaman yürürlükte olan ceza kanununun uygulanmasını, daha sonra yürürlüğe girecek bir kanunun

67 Akbulut (n 55) 107; Hakeri (n 55) 16.

68 Özbek, Doğan ve Bacaksız (n 55) 69; Özen (n 64) 73.

69 Toroslu, Genel Kısım (n 59) 43: Yazara göre TCK’nın 2'nci maddesinde yer verilen bu kural idarenin düzenleyici işlemleriyle suç ihdas edilmesine engel olmayacaktır. TCK'dan daha sonra yürürlüğe giren bir kanun ile idareye suç yaratma yetkisinin verilmesi mümkündür. Eğer bu sonuç istenmiyor ise böylesi bir hükme Anayasa'da yer verilmelidir . Aynı yönde başka görüşler için bkz. Öztürk ve Erdem (n 55) 51, Centel, Zafer ve Çakmut (n 52) 62.

70 Hakeri (n 55) 25-26; Baytaz (n 53) 98-99.

71 Bu konuda yapılan tartışmalar hakkında detaylı bilgi için Bkz. Baytaz (n 53)100-124; Suç oluşturan fiillerin kapsamının kanunla ortaya koyulmasından sonra içeriğinin idarenin düzenleyici işlemleriyle doldurulması anlamına gelen "beyaz hüküm” uygulaması kabahatler hukukunda mümkündür. Bu durum, yukarıda da belirtildiği üzere Kabahatler Kanunu'nun 4'üncü maddesinde açıkça ortaya koyulmuştur.

72765 sayılı TCK’nın 526’ncı maddesinde düzenlenen ve resmi makamların emirlerine riayetsizliği suç halinde getiren hükmün Anayasa’ya aykırı olduğundan bahisle yapılan başvuruda Anayasa Mahkemesi şu açıklamalarla ilgili hükmün Anayasa’ya aykırılık teşkil etmediğine hükmetmiştir: "Yasama organının kanun yaparken bütün olasılıkları göz önünde bulundurarak ayrıntı kuralları da saptamak yetkisi varsa da sık sık değișen durum ve ihtiyaçlar karşısında bu organın, yapısı bakımından ağır işlemesi ve günlük olayları izleyerek zamanında gerekli tedbirleri almasının güçlüğü dolayısıyla kanunda esaslı hükümleri saptadıktan sonra acil olaylarda hükümete veya kimi makamlara tedbir almak yetkisi bırakması da yasama yetkisini kullanmaktan başka bir şey değildir. Bu durum karşısında yasama yetkisinin yürütme organına bırakıldığı gibi bir anlam çıkarmak doğru olmaz. Bundan başka, yukarıda da değinildiği gibi 526. maddenin birinci fikrasında suçun ne gibi eylemleri kapsadığı açıkça belirtildiğine ve cezası da önceden saptandığına göre itiraz konusu kuralın Anayasa'nın 33. maddesi ile Türk Ceza Kanunu'nun 1. maddesindeki 'kanunsuz suç ve ceza olmaz' ilkesine de uymayan bir yönü yoktur.", Anayasa Mahkemesi, E. 1973/12, K. 1973/24, 06.07.1973. Görüleceği üzere bu karar 1961 Anayasası döneminde verilmiştir. Anayasa Mahkemesi’nin son dönemde verdiği kararlarında ise bu usulün kanunilik ilkesine uygun olmadığı vurgulanmaktadır. 
geçmişe yönelik uygulanamamasını ifade $\operatorname{eder}^{73}$. Dolayısıyla ceza hukukunda kural, fiilin işlendiği zaman yürürlükte olan ceza kanunlarının uygulanmasıdır. Bu ilkenin bir sonucu olarak işlendiği zaman suç teşkil etmeyen bir fiilin daha sonra yürürlüğe giren kanunla suç olarak düzenlenmesi halinde faile ceza verilemez ${ }^{74}$. Ancak fiilin işlendiği zamandan daha sonra yürürlüğe giren kanunun fiili suç olmaktan çıkarması ya da önceki kanuna göre daha lehe bir durum öngörmesi halinde bu kanun geriye yürütülebilecektir ${ }^{75}$. Buna göre, ceza hukukunda lehe kanunlar geriye yürütülürler ${ }^{76}$. Lehe kanun, önceden işlenen fiil dolayısıyla hükmedilen cezanın infazının tamamlanmasına kadar uygulanabilir. İnfaz tamamlandıktan sonra ortada lehe kanunu uygulayacak bir durum da kalmayacaktır ${ }^{77}$.

Ceza hukukunda istisnai olarak bazı kanunlar yürürlükten kalksalar dahi yürürlükte bulundukları süre zarfında işlenen suçlara uygulanma kabiliyetini haizdir. Bunlar süreli ve geçici kanunlardır. Süreli kanun, kanun metninde yürürlükte kalacağ1 süre belirtilen kanundur. Geçici kanun ise, belirli bir olayın devamı süresince yürürlükte kalacağı düzenlenen kanunlardır. Bu olaylara savaş veya olağanüstü hal örnek olarak gösterilebilir. Bu kanunlar yürürlükten kalksalar dahi, yürürlükte iken işlenen suçlar bakımından uygulanmaya devam edilirler, yani ileriye dönük olarak etki doğururlar. Bu durum TCK’nın 7’nci maddesinin dördüncü fikrasında da şu şekilde ifade edilmiştir: 'Geçici veya süreli kanunların, yürürlükte bulundukları süre içinde işlenmiş olan suçlar hakkında uygulanmasına devam edilir."

73 Dönmezer ve Erman (n 52) 23.

74 "Bu bağlamda toplumun ihtiyaçlarına göre suç sayılan fiiller için uygulanacak cezalar, nitelik ve nicelik olarak zamanla değişebilmektedir. Suç tarihinden sonra yürürlüğe giren kanunla bir suç için daha hafif bir ceza öngörülebileceği gibi daha ă̆ır bir ceza da belirlenebilir. Hukuki belirliliğin ve hukuk güvenliğinin gereği olarak Anayasa'nın 38. maddesinin birinci fikrasında yer alan "... kimseye suçu işlediği zaman kanunda o suç için konulmuş olan cezadan daha ağır bir ceza verilemez" hükmüyle aleyhe kanunun geçmişe uygulanması yasaklanmıştır. Ceza normlarının zaman bakımından uygulanmasını düzenleyici nitelikteki bu kural kanunilik ilkesinin bir alt ilkesi olan aleyhe kanunun geçmişe uygulanması yasağı olarak ifade edilmektedir. Bu yasak kişi özgürlüğ̈̈ lehine kabul edilmiş bir güvence niteliğindedir.”, Anayasa Mahkemesi, E. 2019/9, K. 2019/27, 11.04.2019, par.16.

75 Öztürk ve Erdem (n 55) 47; Akbulut (n 55) 117; Baytaz (n 53) 143-144.

76 "Suç tarihinden sonra yürürlüğe giren kanunun aynı fiili suç olmaktan çıkarması veya aynı suç için daha hafif bir ceza öngördüğ̈̈ durumlarda ise diğer bir alt ilke olan lehe kanunun uygulanması ilkesi gündeme gelmektedir. Sonraki kanunun fiili suç olmaktan çıkarması veya daha hafif bir ceza öngörmesi durumunda lehe kanundan söz edilir. Aleyhe kanunun geçmişe uygulanması yasağından farklı olarak lehe kanunun uygulanması ilkesine ilişkin bir hükme Anayasa'nın 38. maddesinde açıkça yer verilmemiştir. Bununla birlikte aynı maddede suç için mutlaka fiilin işlendiği zaman yürürlükte olan kanunun öngördüğ̈̈ cezanın verilmesi yönünde bir kural da bulunmamaktadır.", Anayasa Mahkemesi, E. 2019/9, K. 2019/27, 11.04.2019, par.17.

77 Anayasa Mahkemesi, CMK’nın 251'inci maddesinin üçüncü fikrasında düzenlenen ve basit yargılama usulüne ancak hükme bağlanmamıs dosyalarda başvurulabileceğine ilişkin hükmü kanunilik ilkesine aykırı bularak şu açıklamalarla iptal etmiştir: “İtiraz konusu kural belirli bir tarih itibarıla hükme bağlanmış dosyalarda basit yargılama usulünün uygulanamayacağını öngörmektedir. Yukarıda da belirtildiği üzere Kanun’un 251. maddesinin (3) numaralı fikrası basit yargılama usulünün uygulanması sonucunda mahkûmiyet kararı verildiği takdirde verilecek sonuç cezada dörtte bir oranında indirim yapılmasını öngörmektedir. Buna göre itiraz konusu kural yargılama aşamasında olup henüz kesinleşmiş hükümle sonuçlanmamış, dolayısıla yeni yargılama usulünün uygulanabileceği dosyalarda ceza miktarı üzerinde fail lehine etkisi olan basit yargılama usulünün belirli bir tarih itibarıyla hükme bağlanmış dosyalarda uygulanmamasın öngörmek suretiyle Anayasa’nın 38. maddesini ihlal etmektedir. Kuralın bu niteliği ve yargılama üzerindeki etkisi dikkate alındığında Anayasa Mahkemesinin 25/6/2020 tarihli ve E.2020/16 K.2020/33 sayılı kararında ulaştığı sonuçtan ayrılmayı gerektirir bir durum söz konusu değildir.", Anayasa Mahkemesi, E. 2020/81, K. 2021/4, 14.01.2021. 


\section{KIYAS YASAĞI}

Kıyas, kanunda düzenlenmeyen bir hususun kanunda düzenlenen başka bir hususa benzetilerek doldurulması işlemidir ${ }^{78}$. Kıyas işlemi bu yönüyle, kanunda düzenlenmiş bir normun kapsamının ve anlamının ortaya koyulması için yapılan düşünsel bir faaliyet anlamına gelen "yorum” kavramından farklıdır ${ }^{79}$. Ceza hukukunda yorum serbest ancak kıyas yasaktır. Bu sonuç, TCK’nın 2'nci maddesinin üçüncü fıkrasında "Kanunların suç ve ceza içeren hükümlerinin uygulanmasında kıyas yapılamaz" denilmek suretiyle düzenleme altına alınmıştır ${ }^{80}$.

Ceza hukukunda yorum faaliyetinin serbest olduğunu ifade etmekle beraber, kıyasa yol açacak şekilde genişletici yorum yapılması yasaktır. Bu hususa da TCK’nın 2'nci maddesinin üçüncü fıkrasında "Suç ve ceza içeren hükümler, kıyasa yol açacak biçimde geniş yorumlanamaz" denilmek suretiyle yer verilmiştir. Önemle ifade etmek gerekir ki, ceza hukukunda yasak olan genişletici yorum yapmak değil, bu yorum yönteminin kıyasa yol açacak şekilde kullanılmasıdır ${ }^{81}$. Dolayısıyla ceza hukukunda genişletici yorum yapmak serbesttir.

\section{5. ÖRF VE ADET HUKUKUNUN DOĞRUDAN KAYNAK OLAMAMASI}

Kanunilik ilkesinin bir diğer sonucu olarak örf ve adet hukuku ceza hukukunda doğrudan kaynak olamaz $^{82}$. Örf ve adet hukukuna, suç teşkil eden fiiller ile bunlar karşılığında öngörülen yaptırımların belirlenmesi noktasında başvurulamazken, bazı kavramlarının yorumlanmasında örf ve adet hukukundan yararlanmak mümkündür ${ }^{83}$. Örneğin, TCK’nın 125'inci maddesinde düzenlenen hakaret suçunun oluşup oluşmadığı tespit edilirken mahkeme, sarf edilen sözlerin hakaret teşkil edip etmediği değerlendirmesini yaparken örf ve adetten yararlanabilir. Zira bazı sözler toplumun bir kesiminde ya da bölgesinde hakaret olarak algılanmaz iken, başka bir kesim veya bölgesinde hakaret olarak algılanabilir. Hakim, görev yaptığı yerin örf ve adetini göz önünde bulundurarak, ilgili sözün hakaret suçunu oluşturup oluşturmadığına karar verecektir. Böylesi bir tutum kanunilik ilkesine aykırılık teşkil etmez.

78 Öztürk ve Erdem (n 55) 48; Centel, Zafer ve Çakmut (n 52) 53; Akbulut (n 55) 112; Bu kavram hukuk sözlüğünde; "Yasalarda düzenlenen belli bir hukuki durum ve ilişki için konulmuş hükümlerden yararlanarak, o durum ve ilişkiye benzeyen ve fakat yasalarda düzenlenmemiş bir durum ve ilişkiyi çözümleme yöntemi” şeklinde tanımlanmaktadır. Tanım için bkz. Yılmaz (n 6) 766.

79 Özbek, Doğan ve Bacaksız (n 55) 70; Yorum kavramı hukuk sözlüğünde; "Yasa, tüzük, yönetmelik, karar gibi her türlü belgedeki ifadenin açıklanması ve belirlenmesi” şeklinde tanımlanmaktadır. Tanım için bkz. Yılmaz (n 6) 1511.

80 Hakeri (n 55) 29-30.

81 Akbulut (n 55) 113; "Tefecilik suçunun konusunun sadece para ile sınırlandırılması karşısında para yerine geçen kıymetli evrak, altın veya sair menkul kıymetler madde kapsamında bulunmadığından, kanunilik ilkesi gereğince yorum veya kıyas yoluyla bir eşyanın kazanç elde etmek amacıyla ödünç verilmesi suçun konusunu oluşturmayacağından, sanı̆̆ın beraati yerine mahkumiyetine karar verilmesi...”, Yargitay 9 CD, E. 2020/4193, K. 2021/353, 28.01.2021.

82 Baytaz (n 53) 124.

83 Toroslu, Genel Kısım (n 59) 44-45; Öztürk ve Erdem (n 55) 50; Özbek, Doğan ve Bacaksız (n 55) 69; Hakeri (n 55) 25. 


\section{B. SUÇTA VE CEZADA KANUNILIK ILKESININ DISIPLIN HUKUKUNDAKI YANSIMASI}

Anayasa'nın 38'inci maddesinde düzenlenen suçta ve cezada kanunilik ilkesinin disiplin suç ve cezaları bakımından da geçerli olduğu doktrin ve yargı kararlarında genel olarak ifade edilmektedir ${ }^{84}$. Anayasa Mahkemesi de süreklilik kazanan içtihatlarında Anayasa’nın 38'inci maddesinde düzenlenen ceza hukukunun temel ilkelerinin disiplin suç ve cezaları bakımından da geçerli olduğunu şu cümlelerle açılamaktadır: "Burada öncelikle çözümlenmesi gereken konu disiplin suç ve cezalarının Anayasa'nın 38. maddesinde yer alan suç ve cezalar kapsamında olup olmadığıdır. Genel olarak disiplin cezaları kamu görevi ile ilgili bir ceza türü olarak benimsenmektedir. Anayasa’nın 38. maddesinde idari ve adli cezalar arasında bir ayrım yapılmamış, ayrıca ceza yerine geçen güvenlik önlemleri de madde kapsamına alınmıştır. Buna göre, disiplin cezaları Anayasa’nın 38. maddesi kapsamındadır. ${ }^{85}$ " Yüksek mahkeme bu doğrultudaki başka bir kararında Anayasa’nın 38’inci maddesinde adli suç-idari suç ayrımı yapılmadığından bahisle bu maddede yer verilen ilkelerin disiplin suç ve cezaları bakımından da geçerli olduğuna şu cümlelerle hükmetmiştir: "Anayasa'nın 38. maddesinin ilk fikrasında 'Kimse, ... kanunun suç saymadı̆̆ı bir fiilden dolayı cezalandırılamaz' denilerek 'suçun yasalliğı' üçüncü fikrasında da 'ceza ve ceza yerine geçen güvenlik tedbirleri ancak kanunla konulur' denilerek, 'cezanın yasallı̆̆ı' ilkesi getirilmiştir. Anayasa'nın 38.maddesinde idari ve adli cezalar arasında bir ayrım yapılmadı̆̆ından disiplin cezaları da bu maddede öngörülen ilkelere tabidir. ${ }^{86 ”}$

Suçta ve cezada kanunilik ilkesinin disiplin suç ve cezaları bakımından da uygulanma kabiliyeti olduğu kabul edilmekle birlikte, bu ilkenin disiplin hukukundaki uygulama yönteminin nasıl olacağı hususunda doktrinde farklı görüşler bulunmaktadır. Doktrinde bir görüş suçta ve cezada

84 Çağlayan, İdare Hukuku (n 7) 531; Akyılmaz (n 7) 1; Pınar ve Çalışkan (n 12) 21: Yazarlar ceza hukukundaki suçta ve cezada kanunilik ilkesinin dayanağının Anayasa’nın 38'inci maddesindeki düzenleme olduğunu ifade ederken, disiplin suç ve cezalarının dayanağının ise Anayasa’nın 128'inci maddesinde düzenlenen hüküm olduğunu ifade etmektedirler. Kamu hizmeti görevlileriyle ilgili hükümler başlı̆̆ını taşıyan ilgili hüküm şu şekildedir: "Devletin, kamu iktisadi teşebbüsleri ve diğer kamu tüzelkişilerinin genel idare esaslarına göre yürütmekle yükümlü oldukları kamu hizmetlerinin gerektirdiği asli ve sürekli görevler, memurlar ve diğer kamu görevlileri eliyle görülür. Memurların ve diğer kamu görevlilerinin nitelikleri, atanmaları, görev ve yetkileri, hakları ve yükümlülükleri, aylık ve ödenekleri ve diğer özlük işleri kanunla düzenlenir.” Bu hüküm tek başına tüm disiplin suç ve cezalarının anayasal temelini oluşturmak noktasında yeterli değildir. Zira söz konusu hüküm yalnızca memurlar ve diğer kamu görevlileri ile ilgili açıklamalara yer verirken, hakkında disiplin yaptırımı öngörülen kișiler yalnızca bunlarla sınırlı değildir. Örneğin; ilköğretim, ortaöğretim ya da yükseköğretim kurumlarında eğitim-öğretim gören öğrenciler bakımından da disiplin suç ve cezaları öngörülmüş bulunmaktadır. Nitekim, 07.09.2013 tarih ve 28758 sayılı Resmî Gazete’de yayımlanarak yürürlüğe giren Milli Eğitim Bakanlığı Ortaöğretim Kurumları Yönetmeliği’nin 163 vd. maddelerinde kurala bağlanan disiplin hükümleri memurlar ve diğer kamu görevlileri kapsamına dahil olmayan ortaöğretim kurumlarındaki öğrencilere ilişkindir. Dolayısıyla suçta ve cezada kanunilik ilkesinin disiplin hukukunda da geçerli olduğuna ilişkin bir çıkarımı sadece Anayasa’nın 128'inci maddesine dayandırmak hukuken muteber değildir.

85 Anayasa Mahkemesi, E. 1990/12, K. 1991/7, 04.04.1991; Anayasa Mahkemesinin suçta ve cezada kanunilik ilkesinin disiplin hukukunda da geçerli olduğuna hükmettiği bir başka kararında şu açıklamalara yer verilmiştir: "İnsan haklarına önem veren bir ceza infaz sisteminin amaçlarına ulaşabilmesi için, öncelikle Anayasa ve uluslararası belgelerde kabul edilen hukukun temel ilkelerine uygun kurallara dayanması zorunludur. Ceza infaz kurumlarinda uygulanacak disiplin yaptırımlarının da aynen diğer ceza yaptırımları gibi belirlilik ve kanunilik ilkelerine uygun şekilde düzenlenmesi gerekir. Diğer bir ifadeyle bu kurumlarda bulunan hükümlü ve tutukluların hangi fiillerinin disiplin suçu oluşturduğunu açık olarak bilmeleri gerekmektedir.", Anayasa Mahkemesi, E. 2013/28, K. 2013/106, 03.10.2013.

86 Anayasa Mahkemesi, E. 2010/28, K. 2011/139, 20.10.2011: "Anayasa’nın 38. maddesinde idari suç ve cezalar ile adli suç ve cezalar arasında bir ayrım yapılmadığından, her ikisi de bu maddede öngörülen ilkelere tabidir." Aynı yönde başka bir karar için bkz. Anayasa Mahkemesi, E. 2018/110, K. 2018/99, 17.10.2018. 
kanunilik ilkesinin disiplin hukukunda da mutlak olarak uygulanması gerektiğini ifade etmektedir ${ }^{87}$. Doktrinde başka bir görüş suçta ve cezada kanunilik ilkesine disiplin hukukunda ihtiyaç olmadığını savunmaktadır ${ }^{88}$. Ceza hukukunun temel ilkelerinin disiplin hukuku bakımından da geçerli olduğu görüşünde olan yazarların çoğunluğu ise disiplin suç ve cezaları bakımından; cezaların kanuniliği ilkesinin mutlak olarak uygulanması gerektiğini, suçların kanuniliği ilkesinin ise ceza hukukunda olduğu gibi katı bir şekilde uygulanmasına gerek olmadığını, kanun ile disiplin suçu teşkil eden fiillerin çerçevesinin çizilmesinden sonra içeriğinin idarenin düzenleyici işlemleriyle doldurulmasının mümkün olduğunu ifade etmektedirler ${ }^{89}$. Bu durumun gerekçesi olarak, tüm düzeni bozucu fiillerin listesinin yapılmasının imkansız olduğu ve disiplin hukukunda suçta kanunilik ilkesinin benimsenmesi durumunda hızla değişen hayat dinamikleri karşısında kanunla öngörülmemiş bir düzen bozucu fiilin cezalandırılmasının olanaklı olmayacağı ifade edilmektedir ${ }^{90}$. Bu görüşte olan yazarlar Anayasa Mahkemesi ile Danıştay’ın bazı kararlarını da görüşlerine dayanak olarak göstermektedirler ${ }^{91}$.

Hukukumuzda disiplin suç ve cezası öngören bazı kanunlarda bu doğrultuda hükümlere yer verilmektedir. Örneğin DMK’nın 125’inci maddesinde disiplin cezası öngörülen fiiller tek tek sayıldıktan sonra şu hükme yer verilmektedir: "Yukarıda sayılan ve disiplin cezası verilmesini gerektiren fiil ve hallere nitelik ve ağırlıkları itibariyle benzer eylemlerde bulunanlara da aynı neviden disiplin cezaları verilir.” Görüleceği üzere Kanun disiplin suçu teşkil eden fiillerin çerçevesini çizmiş, bu fiillere benzeyen diğer bazı eylemlere de kıyas yoluyla disiplin cezası uygulama noktasında idareye yetki vermiştir ${ }^{92}$. Ancak Kanun bu çerçeveyi çizerken, içeriğin yönetmelikle doldurulmasına ilişkin

87 Hasan Dursun, İdari Suç ve Cezalarda Kanunilik İlkesi (1. Baskı, Adalet Yayınevi 2015) 455-461; Özen (n 64) 73; Yazar şu gerekçelerle suçta kanunilik ilkesinin disiplin hukuku bakımından da geçerli olması gerektiğini ifade etmektedir: "Bize göre, suçta kanunilik ilkesi, disiplin suçlarında da geçerli olmalıdır. Ülkemizde disiplin hukuku (disiplin suç ve cezaları) bakımından temel bir kanun bulunmamaktadır. Çok sayıda farklı kanunlarda disiplin suç ve cezaları düzenlenmiştir. Bu düzenlemelere bakıldı̆̆ında, genel olarak, disiplin suçlarında kanunilik ilkesine uyulmadığ idareye disiplin suçu oluşturma konusunda takdir yetkisi verildiği ve fakat disiplin cezalarında kanunilik ilkesine uyulduğu görülmektedir. Ancak, özel olarak, idarenin disiplin suç ve cezaları konusunda düzenleme yapma yetkisine sahip kılınması, disiplin cezalarında da kanunilik ilkesine uyulmadığını göstermektedir. Anayasa Mahkemesi bir kararında ifade ettiği gibi, disiplin suç ve cezaları da kişi hak ve özgürlüklerini ilgilendirdiği için, KHK ile düzenlenemez. KHK ile düzenlenemeyecek olan disiplin suç ve cezalarının idari düzenlemeler ile düzenlenmesi ve uygulanması Anayasa’ya aykırıdır. Yapılması gereken, bütün disiplin suç ve cezaları için geçerli olacak genel bir disiplin kanunu çıkartılmalıdır”; Disiplin hukukunda kanunilik ilkesine mutlak anlamda uyulması gerektiğini savunan bir başka görüş için bkz. Duman (n 7) 18.

88 Ahmet Erdoğdu, 'Yeni Disiplin Cezaları' (1972) (6-7) Danıştay Dergisi 12, Aktaran: Metin Bulut, 'Kamu Görevlileri Disiplin Hukukunda Kanunilik İlkesini Yeniden Düşünmek' (2018) 6(12) Uyuşmazlık Mahkemesi Dergisi $227,255$.

89 Ulusoy, İdare Hukuku (n 14) 473; Disiplin hukukunda kanunilik ilkesinin mutlak olarak uygulanması gerektiğini savunan görüşler ile disiplin hukukunda kanunilik ilkesini reddeden görüşler hakkında ayrıntılı bilgi için bkz. Bulut (n 88) 243 vd.; Kaşlı (n 24) 44.

90 Şeref Gözübüyük ve Turgut Tan, İdare Hukuku Cilt I Genel Esaslar (10. Bası, Turhan Kitabevi 2014) 881; Kemal Gözler ve Gürsel Kaplan, İdare Hukuku Dersleri (16. Baskı, Ekin Yayınları 2015) 661; Yazarlara göre kamu görevlileri için öngörülen disiplin suçlarını düzenleyen Devlet Memurları Kanunu'nun 125'inci maddesiyle de suçta kanunilik ilkesi katı bir şekilde benimsenmemiş bilakis, "yukarıda sayılan ve disiplin cezası verilmesini gerektiren fiil ve hallere nitelik ve ağırlıkları itibariyle benzer eylemlerde bulunanlara da aynı neviden disiplin cezaları verilir" denmek suretiyle, bu ilkenin ceza hukukunda olduğu gibi katı bir şekilde uygulanmayacağı kabul edilmiş olunmaktadır.

91 Çetintürk (n 54) 147.

92 Boz (n 32) 22. 
herhangi bir hükme yer vermemiştir ${ }^{93}$. Çeşitli yargı makamları bu durumu suçta ve cezada kanunilik ilkesine aykırı bulmamaktadır ${ }^{94}$.

$\mathrm{Bu}$ doğrultuda benzer bir hükme yükseköğretim kurumlarında görevli öğretim görevlilerinin disiplin rejimini düzenleyen 2547 sayılı Yükseköğretim Kanunu’nun 53/D maddesinin beşinci fıkrasında da yer verilmiștir. İlgili fikra şu hükmü içermektedir: "Bu Kanunda sayılan ve disiplin cezası verilmesini gerektiren fiillere nitelik ve ağırlıkları itibarıla benzer fillleri işleyenlere de hangi disiplin fiiline benzediği belirtilerek ayn türden disiplin cezaları verilir." Burada da önce disiplin suçu teşkil eden fiiller sayılmış, ardından bu fiillere nitelik ve ağırlık yönünden benzeyen diğer eylemlere de disiplin cezası verilebilmesi noktasında idareye sınırlı bir alan bırakılmıştır.

Anayasa Mahkemesinin son zamanlarda verdiği kararlar da bu doğrultudadır. Örneğin Anayasa Mahkemesi, avukatlık mesleği mensuplarının disiplin rejimini düzenleyen 1136 sayılı Avukatlık Kanunu’nun 134'üncü maddesinde yer verilen; “Avukatlk onuruna, düzen ve gelenekleri ile meslek kurallarına uymayan eylem ve davranışlarda bulunanlarla, meslekî çalışmada görevlerini yapmayan veya görevinin gerektirdiği dürüstlüğe uygun şekilde davranmayanlar hakkında bu Kanunda yazılı disiplin cezaları uygulanır" hükmünün Anayasa’nın 38'inci maddesinde düzenlenen suçta ve cezada kanunilik ilkesine aykırı olduğu iddiasıyla açlan davada, bu düzenlemenin suçta ve cezada kanunilik ilkesine aykırı olmadığına şu açıllamalarla hükmetmiştir: "Bununla birlikte idari suçlarda kanun koyucunun daha az önem atfettiği bir hukuki değerin ihlal edilmesi nedeniyle hürriyeti bağlayıcı ceza dışında bir yaptırımın öngörülmesi karşısında Anayasänın 38. maddesindeki ilkelerin aynı boyut ve kapsamıla idari suçlara da uygulanması işin mahiyetine uygun düşmemektedir. Bu bağlamda yasama organının ağır işleyen yapısı ile ekonomik ve teknik hayatın hızla değişen ve gelişen şartlar gözetilerek suç ve cezalarda kanunilik ilkesinin idari suçlar yönünden daha esnek uygulanması gerekmektedir. Anayasa Mahkemesi kararlarında vurgulandığı üzere disiplin suçunun kanunda belirlenerek karşıllğında bir disiplin cezasının gösterilmiş olması yeterli olup suç sayılan eylemler ve cezası kanunda gösterildikten sonra yasama organının uzmanlı ve idare tekniğine ilişkin konularda alınacak önlemlerin kamu hizmetlerinin ve toplumsal ihtiyaçların değişkenliği çerçevesinde duyulan

93 Benzer bir düzenlemeye 6413 sayılı Türk Silahlı Kuvvetleri Disiplin Kanunu’nda da yer verilmiştir. Kanun’un 8’inci maddesinin ilk fikrasında "Disiplinsizliği tespit edilen personele disiplin amiri tarafindan bu Kanundaki esaslara uygun olarak disiplin cezası verilir" hükmüne yer verilmiş ve disiplin cezası gerektiren eylemler Kanun'da tek tek sayılmıştır. Aynı maddenin ikinci fikrasında ise DMK'daki düzenlemeye benzer şekilde; "Bu Kanunda belirlenmiş olan disiplinsizliklere nitelik ve ağırlkları itibarıla benzer eylemlerde bulunanlara, eylemleri adli veya askeri suç teşkil etse dahi aynı neviden disiplin cezaları verilebilir” şeklinde bir hüküm bulunmaktadır. Görüldüğü üzere burada da Kanun'da düzenlenen fiillere benzer eylemlerin işlenmesi halinde idareye disiplin cezası verebilme noktasında bir yetki verilmiş ancak benzer eylemlerin yönetmelikle düzenleneceğine ilişkin herhangi bir hükme yer verilmemiştir.

94 "657 sayılı Kanunun 125/4. Maddesinden anlaşılacağı üzere, bir fiilin disiplin cezası ile cezalandırılabilmesi için mutlaka Kanunun 125. maddesinde sayllan fillere lafzen tam olarak uymasının gerekmediği, ortada memur disiplin hukukunun ruhuna aykırı bir fiil bulunması halinde, fiil 125. Maddenin 1. fikrasını $A, B, C, D$ ve E bentlerinin alt bentlerinde sayılan fiillerden hangisine nitelik ve ağırlkları itibariyle en çok benziyor ise, o alt bent kapsamında disiplin cezast verilebileceği tabiidir. Olayda, davacının yukarıda aktarılan paylaşımı yaptığı açık ve ihtilafsı olup, bu paylaşımın disiplin hukukunun ruhuna ters düşen ve disiplin cezası ile cezalandirılması gereken bir fiil olduğu konusunda Dairemizde en ufak bir tereddüt bulunmamaktadır. Ancak, bu filin nitelik ve ağırlğ̆ itibariyle en çok benzer olduğu alt bent, 125. Maddenin 1. fikrasının D bendinin (o) alt bendi, yani 657 sayıl Kanun yukarıda aktarılan 125/D-o maddesi olduğu, davacinin fiilinin 125/Ea ve 125/E-b maddelerine değil, 125/D-o maddesi kapsamında değerlendirilmesi gerektiği sonucuna varılmıştır.", İstanbul Bölge İdare Mahkemesi 2. İDD, E. 2018/2927, K. 2019/829, 24.04.2019. 
gereksinmelere uygunluğunu sağlamak amacıyla yürütme organına yetki vermesi idari kararlarla suç ihdası ve dolayısıyla kanunilik ilkesinin ihlali anlamına gelmemektedir. ${ }^{95}$ " Görüldüğü üzere Anayasa Mahkemesi bu kararı verirken disiplin suçlarında kanun koyucunun daha az önem atfettiği bir hukuki değerin ihlal edildiği ve ekonomik ve teknik hayatın hızla gelişmesi gerçeği karşısında suçta ve cezada kanunilik ilkesini disiplin yaptırımları bakımından da ceza hukukunda olduğu gibi katı uygulanmasının isabetli olmayacağı tespitinden hareket etmiştir.

Disiplin suçlarının yönetmelikle düzenlenebilmesi, hangi fiillerin disiplin cezası gerektiren eylemler olduğunun kapsamının kanunla çizilmeden yalnızca yönetmeliğe bir atıf yapılarak disiplin suç ve cezaları ihdas edilmesinin hukuka uygun olacağı anlamına gelmemektedir ${ }^{96}$. Ezcümle, her ne kadar idarenin düzenleyici işlemleriyle karşılığında disiplin cezası öngörülen eylemlerin belirlenmesi mümkünse de bu eylemleri içerisine alacak kapsamlı bir çerçeve hükme kanunda yer verilmesi elzemdir. Nitekim Anayasa Mahkemesi de Türk Standartları Enstitüsünün (TSE) görev ve yetkilerini düzenleyen 662 sayılı Kanun Hükmünde Kararname’nin 10/A maddesinde yer verilen "Enstitü personelinin izin, disiplin, intibak işleri ile diğer hususlar yönetmelikle belirlenir” şeklinde hükmü şu açıklamalarla Anayasa’ya aykırı bulmuştur: "Buna karşılık suçta ve cezada kanunilik ilkesinin daha esnek uygulandiğı idari suçlar yönünden de suç ve cezalara ilişkin olarak kanun metninde yalnızca genel bir atıfla yetinilmesi yeterli değildir. Anayasa Mahkemesinin 14/1/2015 tarihli ve E.2014/100, K.2015/6 sayılı kararında da vurgulandığı üzere idari suç ve cezalara ilişkin düzenlemelerin içerik bakımından da belirli amacı gerçekleştirmeye elverişli olması gerekir. Bu açıdan kanun metni, bireylerin hangi somut fiil ve olguya hangi hukuksal yaptırımın veya sonucun bağlandığını belirli bir açıklık ve kesinlikte öngörebilmelerine imkân verecek nitelikte olmalıdır. ${ }^{97}$ " Görüleceği üzere Anayasa Mahkemesi, suçta ve cezada kanunilik ilkesinin disiplin yaptırımları bakımından ceza hukukunda olduğu gibi katı bir şekilde uygulanmasına gerek olmadığını ifade etmiş, ancak disiplin yaptırımı gerektiren eylemlerin çerçevesinin kanunla çizilmeden yalnızca bir yönetmeliğe atıf yapılmasını Anayasa’nın 38'inci maddesine aykırı bulmuştur.

Anayasa Mahkemesi başka bir kararında 3201 sayılı Emniyet Teşkilat Kanunu’nun 83’üncü maddesinde yer alan "Gerek inzibat komisyonları tarafindan ve gerek salahiyet dairesinde re'sen verilecek inzibat cezaların icap ettiren fiil ve hareketlerin ne olduğunu ve cezaların derece ve miktarı, polis mesleğinin haiz olduğu hususiyet ve ehemmiyet gözetilerek tanzim edilecek nizamnamede tayin olunur. Memuriyetten ihraç cezası müstesnadır” şeklindeki hükmü Anayasa'ya aykırılık bakımından

95 Anayasa Mahkemesi, E. 2018/30, K. 2018/94, 25.09.2018.

96 "Buna karşıllk suçta ve cezada kanunilik ilkesinin daha esnek uygulandığl idari yaptırımlara ilişkin düzenlemelerin yalnızca kanun metninde yer alması yeterli değildir. Anayasa Mahkemesinin 14/1/2015 tarihli ve E.2014/100, K.2015/6 sayılı kararında da vurgulandiğı üzere söz konusu düzenlemelerin içerik bakımından da belirli amacı gerçekleştirmeye elverişli olması gerekir. Bu açıdan kanun, bireylerin hangi somut fiil ve olguya hangi hukuksal yaptırımın veya sonucun bă̆landığını belirli bir açıklık ve kesinlikte öngörebilmelerine imkân verecek nitelikte olmalıdır.", Anayasa Mahkemesi, E. 2018/73, 27.07.2019.

97 Anayasa Mahkemesi, E. 2018/107, K. 2018, 20.12.2018: “İtiraz konusu kural yaptırım türlerini ve yaptırım konusu eylemleri belirlemediğinden ilgililerin hangi somut fiil ve olguya hangi hukuksal yaptırımın veya sonucun uygulanacağın belirli bir açıklık ve kesinlikte öngörebilmelerine yasal çerçevede imkân tanımamaktadır. Bu nedenle kural suçun ve cezanın kanuniliği ilkesine aykırılık oluşturmaktadır." 
incelemiştir ${ }^{98}$. Yüksek mahkeme bu kararında da öngörülen disiplin suçları ile disiplin cezalarının nelerden ibaret olduğunun belirsiz olması sebebiyle bu hükmü Anayasa’nın 38'inci maddesine aykırı bularak iptal etmiştir.

\section{YÜKSEKÖĞRETIM ÖĞRENCILERI DISIPLIN REJIMININ SUÇTA VE CEZADA KANUNILIK ILKESI BAKIMINDAN DEĞERLENDIRILMESi}

Yukarıda da ifade edildiği gibi, yükseköğretim öğrencileri için öngörülen disiplin rejiminin kanuni dayanağı 2547 sayılı Yükseköğretim Kanunu’nun 54 ve 65’inci maddeleridir. Kanun'un 54’üncü maddesinin (a) bendinde disiplin suçu teşkil eden fiiller; yükseköğretim kurumları içinde veya dışında yükseköğretim öğrenciliği sıfatına, onur ve şerefine aykırı harekette bulunma, öğrenme ve öğretme hürriyetini, doğrudan doğruya veya dolaylı olarak kısıtlama, kurumların sükûn, huzur ve çalışma düzenini bozma, boykot, işgal ve engelleme gibi eylemlere katılma, bunları teşvik ve tahrik etme, yükseköğretim mensuplarının şeref ve haysiyetine veya şahıslarına tecavüz etme veya saygı dışı davranışlarda bulunma ve anarşik veya ideolojik olaylara katılma veya bu olayları tahrik ve teşvik etme şeklinde toplu olarak sayılmıştır. Kanun'da bu fiiller karşılığında öngörülen disiplin cezaları da uyarma, kınama, bir haftadan bir aya kadar veya bir veya iki yarıyıl için kurumdan uzaklaştırma veya yükseköğretim kurumundan çıkarma şeklinde ifade edilmiştir. Kanun'un 65 'inci maddesinde yükseköğretim öğrencilerinin disiplin işlemlerinin yönetmelikle düzenleneceği hükme bağlanmış ve bu doğrultuda Yükseköğretim Kurumları Öğrenci Disiplin Yönetmeliği kabul edilerek yürürlüğe koyulmuştur. Yukarıda bahsedilen disiplin cezalarını öngören fiillerin ne olduğu bu yönetmelikte düzenlenmiştir. Örneğin, yönetmeliğin 4’üncü maddesinin (a) bendinde "Yükseköğretim kurumu yetkililerince sorulan hususları haklı bir sebep olmadan zamanında cevaplandırmamak" eylemi uyarma cezasını gerektiren bir fiil olarak düzenlenmiş iken, 9'uncu maddenin (a) bendinde ise "Mahkeme kararıyla kesinleşmiş olmak kaydıyla, suç işlemek amacıyla örgüt kurmak, böyle bir örgütü yönetmek veya bu amaçla kurulan örgüte üye olmak, üye olmamakla birlikte örgüt adına faaliyette bulunmak veya yardım etmek" fiili yükseköğretim kurumundan çıkarma cezasını gerektiren bir eylem olarak düzenlenmiştir.

Evvelce ifade edildiği gibi, disiplin suçu olarak öngörülen fiillerin tamamının kanunla düzenlenmesine gerek bulunmayıp, bu fiillerin kapsamının kanunla belirlenmesi şartıyla içeriğinin idarenin düzenleyici işlemleriyle doldurma usulü Türk hukuk doktrini ve yargı makamları tarafından Anayasa’nın 38'inci maddesinde düzenlenen suçta ve cezada kanunilik ilkesine aykırılık teşkil etmemektedir. Ancak disiplin cezalarının mutlaka kanunla düzenlenmesi gerekmektedir. Yükseköğretim öğrencileri disiplin rejimi bakımından da bu esaslara uyulmuş ve öğrencilerin işleyeceği disiplin suçları bakımından hangi yaptırımların uygulanacağı kanunda tek tek sayılmıştır ${ }^{99}$. Ancak, yönetmelikte disiplin suçu olarak düzenlenen eylemlerin Kanun hükmünün kapsamında

98 Anayasa Mahkemesi, E. 2015/85, K. 2016/3, 13.01.2016.

99 Yukarıda da ifade edildiği gibi bunlar; uyarma, kınama, yükseköğretim kurumundan bir haftadan bir aya kadar uzaklaştırma, yükseköğretim kurumundan bir veya iki yarıyıl için uzaklaştırma ve yükseköğretim kurumu öğrenciliğinden çıkarma cezasıdır. 
kalıp kalmadığı ve Kanun'da öngörülen fiillerin karşıllğında yer verilen disiplin cezalarının hangileri olduğu hukuki bir belirlemeyi zorunlu kılmaktadır. Zira, Kanun'un 54'üncü maddesinin (a) bendinde yer verilen açılamalar hangi nitelikte eylemlere hangi cezaların verileceğini açık ve belirli bir şekilde ortaya koymuyorsa, bu hükmün Anayasa’nın 38’inci maddesine aykırılı̆̆ı gündeme gelebilecektir ${ }^{100}$. Anayasa Mahkemesi’nin de yukarıda yer verilen bir kararında belirttiği gibi; "eğitim hakkının özüne dokunan ve etkinliğini ortadan kaldıran kısıtlamalardan korunmak için bu kısttlamaların öngörülebilir olması ve meşru amaç çerçevesinde ölçülü olarak yapılması" gerekmektedir ${ }^{101}$.

Doktrinde bazı yazarlar, yükseköğretim kurumu öğrencileri için öngörülen disiplin hükümlerinin kanunda kapsamının açık ve belirli bir şekilde ortaya konulmadan yönetmeliğe bırakılmasını suçta ve cezada kanunilik ilkesine aykırı olduğunu ifade etmektedir ${ }^{102}$. Bu görüşte olan yazarlardan Dursun; 2547 sayılı Kanun'da yükseköğretim öğrencileri için öngörülen disiplin suçlarının tamamına yer verilmediğini, kısmi bir düzenleme yapıldığını, yönetmelikte Kanun'da yer verilemeyen disiplin suçlarının düzenlendiğini ve bu durumun Anayasa’nın 38'inci maddesinde düzenlenen suçta ve cezada kanunilik ilkesine aykırı olduğunu savunmaktadır ${ }^{103}$. Yazar ayrıca, yükseköğretim öğrencileri için öngörülen tüm disiplin suçlarına 2547 sayılı Kanun'da yer verilse bile suçta ve cezada kanunilik ilkesine uyulmuş olunmayacağını ifade etmektedir. Zira, kanunilik ilkesine uygun bir düzenlemeden bahsedilebilmesi için disiplin cezasının hangi fiil ve davranışlar karşıllı̆ıında uygulanacağının açıkça gösterilmesi gerekir. Çünkü, her bir disiplin suçunun cezasının ayrı ayrı gösterilmesi kanunilik ilkesinin "kanunun açıklı̆̆ı" alt ilkesinin bir gereğidir ${ }^{104}$.

100 "Hukuk devletinin temel ilkelerinden biri belirliliktir. Belirlilik ilkesi, yalnızca yasal belirliliği değil daha geniş anlamda hukuki belirliliği de ifade etmektedir. Yasal düzenlemeye dayanarak erişilebilir, bilinebilir ve öngörülebilir olma gibi gereklilikleri karşılaması koşuluyla mahkeme içtihatları ile de hukuki belirlilik sağlanabilir. Hukuki belirlilik ilkesinde asıl olan, bir hukuk normunun uygulanmasıly ortaya çıkacak sonuçların o hukuk düzeninde öngörülebilir olmasıdır. Belirlilik ilkesi, yalnızca yasal belirliliği değil daha geniş anlamda hukuki belirliliği de ifade etmektedir. Yasal düzenlemeye dayanarak erişilebilir, bilinebilir ve öngörülebilir olma gibi gereklilikleri karşılaması koşuluyla mahkeme içtihatları ve yürütmenin düzenleyici işlemleriyle de hukuki belirlilik sağlanabilir. Hukuki belirlilik ilkesinde asıl olan, bir hukuk normunun uygulanmasıyla ortaya çıkacak sonuçların o hukuk düzeninde öngörülebilir olmasıdır. ”, Anayasa Mahkemesi, E. 2018/73, K. 2019/65, 24.07.2019; Aynı yönde açıklamalara yer veren başka bir karar için bkz. Anayasa Mahkemesi, E. 2014/100, K. 2015/6, 14.01.2015.

101 Anayasa Mahkemesi, Başvuru No: 2013/583, 10.12.2014; Danıştay da vermiş olduğu kararlarında, yalnızca disiplin suçu ve cezası öngörülen düzenlemelerin değil, disiplin sorușturmasına ilişikin diğer kuralların da kanunla sevk edilmesi gerektiğini vurgulamaktadır. Örneğin; Yükseköğretim Kanunu’nun 54'üncü maddesinde; disiplin soruşturması yapma, gerekli cezayı verme ve disiplin kuruluna sevk etmekle yetkili kişiler arasında Rektör sayılmamış olmakla birlikte, Yönetmeliğin 12'nci maddesinin birinci fikrasının (d) bendi ile, Rektöre de bazı durumlarda sorușturma açma emri verme yetkisi tanınmıştı. Bu düzenleme Danıştay 8. Dairesi tarafından iptal edilmiştir (Bu karar için bkz. Danıştay, E. 2019/6735, K. 2020/5892). Danıştay İdari Dava Daireleri Kurulu önceki tarihli bir kararında ise söz konusu düzenlemenin iptal talebini reddetmişti. Bkz. Danıştay İDDK., E. 2016/4019, K. 2017/1660.

102 Güneş Okuyucu Ergün ve Eylem Baş, 'Yükseköğretim Kurumları Öğrenci Disiplin Suçları, Cezaları ve Soruşturmalarına İlişkin Bazı Değerlendirmeler’ (2021) 27(1) Marmara Üniversitesi Hukuk Fakültesi Hukuk Araştırmaları Dergisi 26, 29-30; Pınar ve Çalışkan (n 12) 789-793: "Anayasa Mahkemesinin yukarıda anılan kararları, Anayasa’nın 153.maddesi uyarınca herkesi bağladığına göre, yükseköğretim kurumları öğrencilerinin disiplin suç ve cezalarının, belirgin biçimde yasayla düzenlenmesinin; yalnızca ayrıntıların yönetmeliğe bırakılmasının gerekli olduğunu kesin bir şekilde ortaya koymaktadir."

103 Dursun (n 87) 353-354.

104 Dursun (n 87) 354-356: Yazar ayrıca, 2547 sayılı Kanun ile Yönetmelik’te düzenlenen birçok disiplin suç ve cezasının kanunilik ilkesinin sonuçlarından olan ve yukarıda aynı anlama gelen belirlilik ilkesi bağlamında detayları açılanan 
Aynı görüşteki bir başka yazar olan Şen’e göre de; Yükseköğretim Kurumları Öğrenci Disiplin Yönetmeliği ile sevk edilen disiplin rejiminde suçta ve cezada kanunilik ilkesine uyulmamış, Kanun'da yer verilmeyen birçok fiil yönetmelik ile disiplin suçları kapsamına sokulmuştur ${ }^{105}$.

Şimdi bu mesele Anayasa Mahkemesi kararları ışı̆̆ında irdelenecektir.

İlk olarak, Anayasa Mahkemesinin mülga Yükseköğretim Kurumları Öğrenci Disiplin Yönetmeliği döneminde verdiği bir kararı analiz etmekte yarar vardır. Kanuni dayanağı halen uygulanmakta olan Yönetmelikte olduğu gibi 2547 sayılı Kanun'un 54 ve 65'inci maddeleri olan mülga Yükseköğretim Kurumları Öğrenci Disiplin Yönetmeliğinnin 10’uncu maddesinin (e) bendinde; “kanun dışı kuruluşlar adına faaliyet yapmak veya yardımda bulunmak" fiili öğrencilikten çıkarma cezası öngörülen bir disiplin suçu olarak düzenlenmişti.

Bir terör örgütü içerisinde faaliyet gösterdiği tespit edilen yükseköğretim kurumu öğrencisine bu hükme dayanılarak öğrencilikten çıarma cezası verilmiş, verilen disiplin cezasının doğrudan kanunla düzenlenmediğinden bahisle eğitim hakkının ihlal edildiği gerekçesiyle Anayasa Mahkemesine bireysel başvuru yolu ile müracaat edilmiştir. Yüksek mahkeme, mevcut Yükseköğretim Kurumları Öğrenci Disiplin Yönetmeliğinin uygulanmasına da ışı tutacak şekilde ilgili düzenlemenin Anayasảnın 38'inci maddesinde düzenlenen suçta ve cezada kanunilik ilkesine aykırı olmadığına şu cümlelerle hükmetmiştir: "Bu kapsamda yükseköğrenime ilişkin disiplin suç ve cezaları 2547 sayılı Kanun’un 54. maddesinde düzenlenmiştir. Söz konusu maddede yükseköğrenim kurumları içinde veya dışında "anarşik veya ideolojik olaylara katılan veya bu olayları tahrik ve teşvik eden eylem başka bir suçu oluştursa bile ayrıca uyarma, kınama, bir haftadan bir aya kadar veya bir veya iki yarıyıl için kurumdan uzaklaştırma veya yükseköğretim kurumundan çıkarma cezalarını" verileceği hüküm altına alınmış... Bu şekilde Kanun'da disiplin cezasını gerektiren eylemler topluca sayılmış ve bunlara verilebilecek cezalar topluca ifade edilmiştir. Kanun, hangi eyleme hangi cezanın verileceğini ise Yönetmelike bırakmıştır... Dolayısıly 2547 sayıl Kanuna uygun olarak kabul edilen mülga Yönetmelik'in ilgili hükmünün öngörülebilir ve ulaşılabilir bir şekilde 'Kanun dışı kuruluşlara üye olma,

"kanunların açıklığı" ilkesine de aykırı olduğunu ifade etmektedir. Örneğin, Yönetmeliğin "Kınama Cezasını Gerektiren Disiplin Suçları" başlıklı 7’nci maddesinin ikinci fikrasının (a) bendinde "öğrencilik sıfatının gerektirdiği itibar ve güven duygusunu sarsacak nitelikte davranışlarda bulunmak" şeklindeki düzenleme oldukça muğlak ifadeler içerdiğinden suçta ve cezada kanunilik ilkesinin sonuçlarından olan "kanunların açıklı̆ı̆” ilkesine aykırılık teşkil etmektedir.

105 Ersan Şen, 'Disiplin Hukuku ve Öğrenci Disiplin Yönetmeliği' (HukukiHaber.net, 22 Haziran 2015) <https://www. hukukihaber.net/disiplin-hukuku-ve-ogrenci-disiplin-yonetmeligi-makale,4062.html> 2 Nisan 2021: "Belirtmeliyiz ki; her ne kadar disiplin cezaları 'kanunilik' prensibine uygun olsa da, aşağıda kısaca yer verdiğimiz disiplin suçları bakımından ayn tespitte bulunamayacağımız bir gerçektir. 'Disiplin suç ve cezalarında kanunilik' prensibine göre, işlendiği tarih itibariyle bir eylemi net bir şekilde disiplin suçu sayan ve ceza öngören yazılı hukuk kuralı olmadıkça kimseye ceza verilemeyeceği gibi, bir kimse hakkında yazll hukuk kuralında öngörülen suçtan ve cezadan başka, örneğin kiyas yaparak veya daha fazla ceza tayini yoluyla yaptırım uygulanamaz. Maalesef bu Yönetmelikte ve genel olarak tüm disiplin kurallarında, özellikle 'kanunilik' prensibi açısından keyfiliğin olduğu ve bu sorunun çözümünde olumlu adımlar atılmadığ görülmektedir. Bu keyfilikten başka, disiplin suçlarının çok ağır olduğu ve her yöne çekilebilecek muğlaklı̆̆a da sahip olduğu, ayrıca her gün gelişen bilim ve teknik karşısında yetersiz kaldığı, yeni disiplin suçları ile ilgili yeterli düzenlemelerin yapılmadığı bir gerçektir." Görüldüğü üzere yazar yükseköğretim kurumları öğrencileri için öngörülen disiplin suçlarının kanunda kapsamı ortaya koyulmadan yönetmelikle düzenlenmesini suçta ve cezada kanunilik ilkesine aykırı bulmakta ve bu durumun disiplin kuralları öngören düzenlemelerde sıklıkla yapıldığını vurgulamaktadır.

Dursun (n 87) 353-354. 
bu kuruluşlar adına faaliyet yapma veya yardımda bulunma' eylemine karşıllk disiplin yaptırımını kabul ettiğinden başvurucunun eğitim ve öğrenim hakkına yönelik müdahalenin kanuni dayanağının olduğu açıktır. ${ }^{106 ” ~ A n a y a s a ~ M a h k e m e s i ~ b u ~ k a r a r ı n d a ~ k ı s a c a, ~ Y u ̈ k s e k o ̈ g ̆ r e t i m ~ K u r u m l a r ı ~ O ̈ g ̆ r e n c i ~ D i s i p l i n ~}$ Yönetmeliğìinin 10'uncu maddesinin (e) bendinde düzenlenen "kanun dışı kuruluşlar adına faaliyet yapmak veya yardımda bulunmak" eylemini, 2547 sayılı Kanun'un 54'üncü maddesinde düzenlenen "Anarşik veya ideolojik olaylara katılmak veya bu olayları tahrik ve teşvik etmek" eyleminin kapsamına dahil olduğunu, dolayısıyla öğrenciye verilen disiplin cezasının yasal dayanağının bulunduğunu ifade etmiştir. Görüldüğü üzere Anayasa Mahkemesi, yükseköğretim öğrencileri için öngörülen disiplin cezalarının Kanunda tek tek sayılması ve bu cezaların karşıllğında öngörüldüğü disiplin suçlarının kapsamının da belirli, açık ve ulaşılabilir bir şekilde ortaya koyulduğundan bahisle, ilgili öğrenciye verilen öğrencilikten çıkarma cezasını suçta ve cezada kanunilik ilkesine aykırı bulmamıştır.

Anayasa Mahkemesi, yine yasal dayanağ 2547 sayılı Kanun’un 54 ve 65’inci maddelerinin olduğu mülga Yükseköğretim Kurumları Öğrenci Disiplin Yönetmeliği döneminde gerçekleşen benzer bir olayda, öğrenci hakkında yönetmeliğe dayanılarak öğrencilikten çıkarma cezasının verilmesini şu açıklamalarla hukuka aykırı bulmamıştır: "Başvurucu, disiplin cezasına neden olan Yönetmelik'in 10. maddesinin (e) bendinin 2547 sayıl Kanun'da açıkça yer almadığını ileri sürmüştür. 2547 sayıl Kanuna uygun olarak kabul edilen mülga Yönetmelik’in ilgili hükmünün öngörülebilir ve ulaşılabilir bir şekilde "kanun dışı kuruluşlara üye olma, bu kuruluşlar adına faaliyet yapma veya yardımda bulunma" eylemine karşıllk disiplin yaptırımın kabul ettiğinden başvurucunun eğitim ve öğrenim hakkına yönelik müdahalenin kanuni dayanağının olduğu açıktır. ${ }^{107}$ " Görüldüğü üzere Anayasa Mahkemesi; disiplin hukukunda, disiplin suçu teşkil eden fillerin kapsamının kanunla ortaya koyulmasından sonra içeriğinin idareye verilecek yetki uyarınca yönetmelikle düzenlenmesinin Anayasa’nın 38'inci maddesinde düzenlenen suçta ve cezada kanunilik ilkesine uygun olduğu, 2547 sayılı Kanun’un 54 ve 65 'inci maddelerinin ilgili yönetmeliğin yasal dayanağ 1 olduğu ve söz konusu yönetmelik hükümlerinin açık, belirlenebilir ve ulaşılabilir olmasından bahisle, mülga Yükseköğretim Kurumları Öğrenci Disiplin Yönetmeliği’ne dayanılarak yükseköğretim öğrencilerine disiplin cezası verilmesini hukuka uygun bulmuştur.

Bahsedilen yönetmelik, 18/8/2012 tarihli ve 28388 sayılı Resmi Gazetede yayımlanarak yürürlüğe giren Yükseköğretim Kurumları Öğrenci Disiplin Yönetmeliği ile yürürlükten kaldırılmıștır. Mevcut yönetmelik doğrultusunda yükseköğretim kurumları öğrencilerine verilen disiplin cezalarını

106 Anayasa Mahkemesi, Selçuk Taşdemir Başvurusu, 2013/7860, 03.03.2016.

107 Anayasa Mahkemesi, 13.04.2016, İdris Esen Başvurusu, 2013/7171, 13.04.2016; Anayasa Mahkemesi’nin çok benzer açıklamaları içerisinde barındıran başka bir kararı için bkz. Anayasa Mahkemesi, 2014/5881, 15.02.2017: "Yükseköğretim öğrencilerinin disiplin işlemlerine ilişkin soruşturma usulleri, yetkiler ve cezalar 2547 sayıl Kanun'un 54. maddesinde düzenlenmiştir. Başvurucuya verilen yükseköğretim kurumundan çıkarma disiplin cezası da aynı maddede yer almaktadır. Yönetmelik'in 10. maddesi de söz konusu Kanun hükmüne dayanarak çıkarılmıştır. Başvurunun sonucuna ve mevcut başvurunun koşullarına göre yukarıda zikredilen kuralların yeterince “öngörülebilir” olup olmadiğı konusunda daha ileri bir değerlendirme yapılması gerekli görülmemiştir. Yapılan değerlendirmeler neticesinde 2547 sayılı Kanun’un 54. maddesinin (a) bendi ile Yönetmelik'in 10. maddesinin kanunla sınırlama ölçütünü karşıladığı sonucuna varılmıştır”; Anayasa Mahkemesi başka bir kararında üniversite yönetimine verdiği dilekçenin içeriği sebebiyle öğrenci hakkında ilgili yönetmeliğe dayanılarak disiplin cezası verilmesini suçta ve cezada kanunilik ilkesine aykırı bulmamıştır. Bkz. Anayasa Mahkemesi, 2014/5881, 15.02.2017. 
kanunilik ilkesi bağlamında inceleyen bir Anayasa Mahkemesi kararı tespit edilememiştir. Ancak Anayasa Mahkemesỉnin mülga yönetmelik döneminde gerçekleşen olaylar hakkında verdiği ve yakın tarihli olan bu kararlarda, 2547 sayılı Kanun'un 54 ve $65^{\prime}$ inci maddelerine dayanılarak çıkarılan yönetmelik hükmü uyarınca öğrencilere disiplin cezası verilmesi yönündeki durumu suçta ve cezada kanunilik ilkesine aykııı bulmama yönündeki içtihadını yeni yönetmelik döneminde de sürdürmesi kuvvetle muhtemeldir. Zira 18/8/2012 tarihli ve 28388 sayılı Resmi Gazetede yayımlanarak yürürlüğe giren Yükseköğretim Kurumları Öğrenci Disiplin Yönetmeliği’nin yasal dayanağı da önceki yönetmelikte olduğu gibi 2547 sayılı Yükseköğretim Kanunu’nun 54 ve 65'inci maddeleridir. Dolayısıyla, yönetmelikte yer verilen disiplin suç ve cezalarının kanuni dayanağında bir değişiklik bulunmamaktadır. Bunun aksine mevcut yönetmelik, eski yönetmeliğe nazaran öğrenciler hakkında öngörülen disiplin suçlarının sayısını azaltmış, bazı disiplin suçlarının işlenmiş sayılmasını da daha zor şartlara bağlamıştır. Örneğin, mülga Yükseköğretim Kurumları Öğrenci Disiplin Yönetmeliği’nin 10'uncu maddesinin (e) bendinde "Kanun dışı kuruluşlara üye olmak, bu kuruluşlar adına faaliyet yapmak veya yardımda bulunmak" fiili yükseköğretim kurumundan çıkarma cezasını gerektiren bir disiplin suçu olarak düzenlenmişti. Yeni Yönetmeliğin bu hükme karşıllk gelen ve yükseköğretim kurumundan çıkarma cezası gerektiren disiplin suçuna ise 9'uncu maddenin (a) bendinde yer verilmiştir. İlgili düzenleme şu hükmü içermektedir: "Mahkeme kararıyla kesinleşmiş olmak kaydıyla, suç işlemek amacıyla örgüt kurmak, böyle bir örgütü yönetmek veya bu amaçla kurulan örgüte üye olmak, üye olmamakla birlikte örgüt adına faaliyette bulunmak veya yardım etmek.” Görüldüğü üzere bu düzenleme ile yasa dışı faaliyetlerde bulunan kişi hakkında yükseköğretim kurumundan çıkarma cezasının verilebilmesi için hem faaliyette bulunulan yasadışı organın suç işlemek amacıyla kurulan bir örgüt ${ }^{108}$ olması şartı aranmış hem de öğrencinin bu örgütleri kurduğuna veya yönettiğine, bu örgütlere üye olduğuna ya da bu örgütlere yardım ettiğine dair kesinleşmiş bir mahkûmiyet kararı gerekli görülmüştür. Dolayısıyla yeni yönetmeliğin eskisine nazaran öğrenciler bakımından daha güvenceli bir içeriği bulunmaktadır. Durum böyle olunca Anayasa Mahkemesi’nin eski yönetmelik döneminde gerçekleşen olaylar hakkında verdiği; disiplin suçları öngören yönetmeliğin yasal dayanağının bulunduğu, yönetmelik hükümlerinin kanunla çizilen çerçeve kapsamında kaldığı ve bu sebeple yükseköğretim kurumları öğrencilerine verilen disiplin cezalarının Anayasa’nın 38’inci maddesinde yer verilen suçta ve cezada kanunilik ilkesine aykırılık teşkil etmediği yönündeki içtihadını, yukarıda yer verilen doktrindeki eleştirilere rağmen yeni yönetmelik döneminde de sürdürmesi muhtemeldir.

108 Suç işlemek amacıyla örgüt kurmak veya yönetmek, bu örgütlere üye olmak ve bu örgütlere yardım etmek suçları TCK’nın 220 'nci maddesinde düzenlenmiștir. Bu madde, örgüt suçları bakımından sevk edilen genel ve tamamlayıcı bir hüküm niteliğindedir. Kurulan, yönetilen, üye olunan veya yardım edilen örgütün başka bir hukuki düzenleme kapsamında kalan örgüt olması halinde öncelikli olarak o hükümler uygulanır. Örneğin; söz konusu örgütün TCK’da düzenlenen devletin güvenliğine karşı suçlar ile anayasal düzene ve bu düzenin işleyişine karşı suçlar’’ işlemek maksadıyla kurulması halinde TCK'nın 314'üncü maddesi hükümleri, Terörle Mücadele Kanunu’nun 1'inci maddesinde sayılan amaçları gerçekleștirmek için kurulması halinde aynı Kanun’un 7’nci maddesinin ikinci fikrası hükümleri uygulanacaktır. Bu düzenlemelerde yer verilmeyen hususlar bakımından ise, genel ve tamamlayıcı bir hüküm olması sebebiyle TCK’nın 220 'nci maddesi uygulanacaktır. Bkz. Vesile Sonay Evik, 'Silahlı Örgütlenme Suçu' (2006) (1) Galatasaray Üniversitesi Hukuk Fakültesi Dergisi 101, 127; Nevzat Toroslu, Ceza Hukuku Özel Kısım (8.Baskı, Savaş Yayınevi 2015) 267; Önder Tozman, Suç İşlemek Amacıyla Örgüt Kurma Suçu (2.Baskı, Seçkin Yayıncılık 2017) 253. 


\section{SONUÇ}

Yükseköğretim kurumlarında eğitim-öğretim gören öğrenciler için öngörülen disiplin suç ve cezalarını içeren hükümlere, Yükseköğretim Kanunu’nun 54 ve 65’inci maddeleri ile Yükseköğretim Kurumları Öğrenci Disiplin Yönetmeliği’nde yer verilmiştir. Kanunda disiplin suçu olarak öngörülen fiillerin kapsamı ortaya koyulmuş, bu fiiller karşılığında verilebilecek tüm disiplin cezaları tek tek sayılmış ancak disiplin cezası gerektiren eylemlerin detaylı bir şekilde ortaya koyulması Kanun'un 65 'inci maddesi uyarınca Yükseköğretim Kurumunun çıkaracağı yönetmeliğe bırakılmıştır. Türk doktrinindeki genel görüşe ve Anayasa Mahkemesinin yerleşik içtihatlarına göre disiplin hukuku bakımından cezada kanunilik ilkesinin mutlak olarak uygulanması gerekmekle birlikte, suçta kanunilik ilkesinin ceza hukukunda olduğu kadar katı bir şekilde uygulanmasına gerek görülmemektedir. Disiplin suçu teşkil eden fiillerin genel çerçevesinin Kanunla çizilmesi kaydıyla, içeriğinin idarenin düzenleyici işlemleriyle doldurulması mümkündür. Anayasa Mahkemesi de bu yönde kararlar vermektedir.

Disiplin suçu olarak öngörülebilecek eylemlerin idarenin düzenleyici işlemleriyle ortaya koyulabilecek olması, kanunla bu fiillerin kapsamının açık, belirgin ve kapsamlı bir şekilde ortaya koyulmadan yönetmeliklere atıf yapmakla yetinmesi bu düzenlemeleri suçta ve cezada kanunilik ilkesine aykırı hale getirecektir. Burada, yükseköğretim kurumları öğrencileri için öngörülen disiplin suçlarının ve bu eylemler karşılığında öngörülen disiplin cezalarının Kanun'da toplu halde sayılması ancak hangi nitelikteki eyleme hangi cezanın verileceğinin belirtilmeyerek yönetmeliğe atıf yapmakla yetinilmesinin suçta ve cezada kanunilik ilkesine aykırılık teşkil edeceği ifade edilebilir. Nitekim, doktrinde de bazı yazarlar mevcut disiplin rejimi düzenlemelerinin suçta ve cezada kanunilik ilkesine aykırı olduğunu ifade etmektedirler. Anayasa Mahkemesi ise mülga Yükseköğretim Kurumları Öğrenci Disiplin Yönetmeliği döneminden itibaren verdiği ve süreklilik kazanan içtihatlarında; ilgili disiplin rejimi düzenlemelerinin kapsamının kanunla ortaya koyulduğu, içeriğinin ise yönetmelikle belirleneceğinin yine aynı Kanun'un 65'inci maddesinde belirtildiği ve hem Kanun hem de yönetmelik hükümlerinin açık, belirli ve ulaşılabilir olması gerekçeleriyle yükseköğretim kurumları öğrencileri için öngörülen disiplin rejiminin suçta ve cezada kanunilik ilkesine aykırı olmadığı görüşünü benimsemektedir.

\section{KAYNAKÇA}

Akbulut B, Ceza Hukuku Genel Hükümler (6. Bask1, Adalet Yayınevi 2019).

Akyılmaz B, 'Anayasal Esaslar Çerçevesinde Kamu Personeli Disiplin Hukuku Ve Uygulamadaki Sorunlar' (2002) 6(2) Ankara Hacı Bayram Veli Üniversitesi Hukuk Fakültesi Dergisi 241-262.

Aslan Z ve Altındağ H, Memurların Disiplin ve Ceza Soruşturması (2. Baskı, Seçkin Yayıncılık 2019).

Baytaz AB, Kanunilik İlkesi Bağlamında Ceza ve Ceza Muhakemesi Hukukunda Yorum (1. Baskı, On İki Levha Yayıncillk 2018).

Boz SS, 'Memur Disiplin Hukukuna Hakim Olan Temel İlkeler' (2017) 25(2) Selçuk Üniversitesi Hukuk Fakültesi Dergisi 15-41.

Bulut M, 'Kamu Görevlileri Disiplin Hukukunda Kanunilik İlkesini Yeniden Düşünmek' (2018) 6(12) Uyuşmazlık Mahkemesi Dergisi 227-278. 
Canoğlu VC, 'Disiplin Soruşturmasında Delil ve İspat' (2018) 138 Türkiye Barolar Birliği Dergisi 231-272.

Centel N, Zafer H ve Çakmut Ö, Türk Ceza Hukukuna Giriş (8. Bası, Beta Yayınları 2014).

Çağlayan R, İdari Ceza Hukuku (1. Baskı, Adalet Yayınevi 2013).

Çağlayan R, İdare Hukuku Dersleri (7. Baskı, Seçkin Yayıncılık 2019).

Çetintürk E, 'Anayasa Mahkemesi Kararları Işı̆̆ında İdarenin Düzenleyici İşlemleriyle Suç ve Ceza Konulamaz İlkesi' (2017) 5(9) Uyuşmazlık Mahkemesi Dergisi 39-180.

Çınarlı S, 'Yükseköğretim Kurumlarında Disiplin Soruşturması Sorunu ve Alman Disiplin Mahkemeleri Modeli Önerisi' (2011) 19(1) Selçuk Üniversitesi Hukuk Fakültesi Dergisi 39-63.

Çiftçioğlu CT, '2802 Sayılı Hakimler ve Savcılar Kanununa Göre Hakim ve Savcıların Disiplin Soruşturmaları' (2013) 13(1) Dokuz Eylül Üniversitesi Hukuk Fakültesi Dergisi 127-157.

Demirbaş T, Ceza Hukuku Genel Hükümler (15. Baskı, Seçkin Yayıncılık 2020).

Dönmezer S ve Erman S, Nazari ve Tatbiki Ceza Hukuku Cilt I (14. Bas1, Der Yayınları 2016).

Duman B, Yükseköğretim Ceza ve Disiplin Soruşturması (5. Baskı, Seçkin Yayıncılık 2014).

Dursun H, İdari Suç ve Cezalarda Kanunilik İlkesi (1. Baskı, Adalet Yayınevi 2015).

Erem F, Ümanist Doktrin Açısından Türk Ceza Hukuku Cilt I Genel Hükümler (8. Baskı, Ankara Üniversitesi Hukuk Fakültesi Yayınları 1968).

Evik VS, 'Silahlı Örgütlenme Suçu' (2006) (1) Galatasaray Üniversitesi Hukuk Fakültesi Dergisi 101-133.

Gözler K ve Kaplan G, İdare Hukuku Dersleri (16. Baskı, Ekin Yayınevi 2015).

Gözübüyük Ş ve Tan T, İdare Hukuku Cilt I Genel Esaslar (10. Bas1, Turhan Kitabevi 2014).

Güveyi Ü, 'Memur Disiplin Hukukunda Mobbing' (2013) 17(1-2) Gazi Üniversitesi Hukuk Fakültesi Dergisi 1455-1481.

Hakeri H, Ceza Hukuku Genel Hükümler (22. Baskı, Adalet Yayınevi 2019).

Işılklar C, Teoride ve Uygulamada Kamu Disiplin Yaptırımları (1 .Baskı, Adalet Yayınevi 2019).

Kaşlı E, Polis Disiplin Hukuku (1. Baskı, Adalet Yayınevi 2020).

Okuyucu Ergün G ve Baş E, 'Yükseköğretim Kurumları Öğrenci Disiplin Suçları, Cezaları ve Soruşturmalarına İlişkin Bazı Değerlendirmeler' (2021) 27(1) Marmara Üniversitesi Hukuk Fakültesi Hukuk Araştırmaları Dergisi 26-47.

Özbek VÖ, Doğan K ve Bacaksız P, Türk Ceza Hukuku Genel Hükümler (11. Baskı, Seçkin Yayıncılık 2020).

Özen M, Ceza Hukuku Genel Hükümler Dersleri (3. Baskı, Adalet Yayınevi 2019).

Öztürk B ve Erdem MR, Uygulamalı Ceza Hukuku ve Güvenlik Tedbiri Hukuku (20. Baskı, Seçkin Yayıncılık 2020).

Pınar İ ve Çalışkan Ö, Açıklamalı-İçtihatlı Disiplin Suç ve Cezaları ve Disiplin Soruşturması (1. Baskı, Seçkin Yayıncilik 2013).

Şen E, 'Disiplin Hukuku ve Öğrenci Disiplin Yönetmeliği' (HukukiHaber, 22 Haziran 2015) <https://www. hukukihaber.net/disiplin-hukuku-ve-ogrenci-disiplin-yonetmeligi-makale,4062.html> Erişim Tarihi 2 Nisan 2021.

Şen E, 'İdari Ceza Hukuku’ (1994) (8) İstanbul Üniversitesi Siyasal Bilgiler Fakültesi Dergisi 21-50.

Toroslu H, Ceza Müeyyidesi (1. Baskı, Savaş Yayınevi 2010).

Toroslu N, Ceza Hukuku Genel Kısım (19. Baskı, Savaş Yayınevi 2013).

Toroslu N, Ceza Hukuku Özel Kısım (8.Baskı, Savaş Yayınevi 2015).

Tosun MU ve Öztürk İ, 'Yükseköğretim Hizmeti Karşıllğında Devlet ve Vakıf Yükseköğretim Kurumlarına Yapılan Ödemelerin Hukuki Niteliği' (2017) 13(148) Legal Mali Hukuk Dergisi 765-822. 
Tozman Ö, Suç İslemek Amacıyla Örgüt Kurma Suçu (2. Baskı, Seçkin Yayıncılık 2017).

Ulusoy AD, İdari Yaptırımlar (1. Baskı, On İki Levha Yayıncılık 2013).

Ulusoy AD, Yeni Türk İdare Hukuku (3. Bask1, Yetkin Yayınları 2020).

Yılmaz E, Hukuk Sözlüğ̈̈ (10. Baskı, Yetkin Yayınları 2011).

Yiğit U ve Öztürk İ, Yargı Hukuku (1. Baskı, Adalet Yayınevi 2020). 